\title{
The response of soil physicochemical properties to tillage and soil fertility resources in Central Highlands of Kenya
}

\author{
Milka N. Kiboi, ${ }^{1}$ Felix K. Ngetich, ${ }^{1}$ Anne Muriuki, ${ }^{2}$ Noah Adamtey, ${ }^{3}$ Daniel Mugendi ${ }^{1}$ \\ ${ }^{1}$ Department of Land and Water Management, University of Embu, Embu, Kenya; ${ }^{2}$ National Agricultural \\ Research Laboratories, Kenya Agricultural and Livestock Research Organization, Nairobi, Kenya; \\ ${ }^{3}$ Department of Soil Sciences, Research Institute of Organic Agriculture (FiBL), Frick, Switzerland
}

\begin{abstract}
To attain agricultural sustainability, use of soil resources and tillage requires equal consideration for chemical and physical components of soil fertility. We assessed responses of selected soil physical and chemical properties to tillage and soil fertility amending resources. The study was carried out in Meru South and Kandara sub-counties located in the Central Highlands of Kenya for four cropping seasons. The experimental design was split-plot with tillage as the main factor - conventional $\left(\mathrm{D}_{15}\right)$ - and minimum
\end{abstract}

Correspondence: Milka N. Kiboi, Department of Land and Water Management, University of Embu, , P.O. Box 6-60100, Embu, Kenya. Tel.: +254.723.766.490

E-mail: milka.kiboi@gmail.com

Key words: Clayey soils; organic inputs; soil organic carbon; tillage.

Acknowledgements: the authors are thankful to the Swiss Agency for Development and Cooperation (SDC) and Swiss National Science Foundation (SNSF) in the Swiss Programme for Research on Global Issues for Development ( $\mathrm{r} 4 \mathrm{~d}$ programme) and Research Institute of Organic Agriculture (FiBL), Switzerland for providing financial support (Grant No. 400540-152224) through the Organic Resource Management for Soil Fertility project to conduct the trials. We appreciate Kangutu Primary School in Meru South and Kenya Agricultural and Livestock Research Organisation (KALRO) in Kandara for providing the field experimental sites.

Contributions: MNK was involved in the data collection and analysis, interpretation of the results and manuscript writing; FKN participated in the supervision of field experiments implementation, laboratory analysis, manuscript reviewing; AM participated in the manuscript reviewing; NA contributed in the design of the field experiment and manuscript reviewing; DM participated in the manuscript reviewing.

Conflict of interests: the authors declare no potential conflict of interests.

Received for publication: 2 January 2019.

Revision received: 1 November 2019.

Accepted for publication: 11 November 2019.

${ }^{\circledR}{ }^{C}$ Copyright: the Author(s), 2020

Licensee PAGEPress, Italy

Italian Journal of Agronomy 2020; 15:1381

doi:10.4081/ija.2020.1381

This article is distributed under the terms of the Creative Commons Attribution Noncommercial License (by-nc 4.0) which permits any noncommercial use, distribution, and reproduction in any medium, provided the original author(s) and source are credited.
$\left(D_{0}\right)$ tillage and soil fertility resources (SFR) as sub-factors - mineral fertilizer $(\mathrm{F})$, crop residues + fertilizer $(\mathrm{RF})$, residues + fertilizer + animal manure (RFM), residues + Tithonia diversifolia + manure (RTiM), residues + Tithonia diversifolia + phosphate rock (Minjingu) (RTiP), residues + manure + legume intercrop (RML) and control (no input). Compared with control, aggregate stability was significantly higher on average under SFRs with sole organics by $19 \%$ in Meru South. Total N and available P were higher under integration of fertilizer and organics in both sites. Calcium increased under sole organic or integration with fertilizer in Meru South and under sole organics in Kandara. Magnesium significantly increased under all SFRs compared with control in Kandara. Soil organic carbon significantly $(\mathrm{P}=0.02)$ increased under $\mathrm{D}_{0}$ by $6 \%$ compared to $\mathrm{D}_{15}$ in $0-5 \mathrm{~cm}$ depth in Kandara. Application of RTiM had the highest SOC in all depths' at Meru South. SOC significantly increased under RTiP and RML by $11 \%$ in $0-5 \mathrm{~cm}$ depth and under RML by $13 \%$ in $5-10 \mathrm{~cm}$ depth at Kandara. Mineral-N $\left(\mathrm{NO}_{3}{ }^{-}-\mathrm{N}\right.$ and $\left.\mathrm{NH}_{4}{ }^{+}-\mathrm{N}\right)$ was higher under $\mathrm{D}_{0}$ at planting compared with $\mathrm{D}_{15}$ in Meru South. In Kandara, $\mathrm{NO}_{3}{ }^{-}-\mathrm{N}$ and $\mathrm{NH}_{4}{ }^{+}-\mathrm{N}$ were significantly higher by $17 \%$ and $30 \%$, respectively under $\mathrm{D}_{0}$ compared with $\mathrm{D}_{15}$ at planting during SR16 season. Higher mineral $\mathrm{N}$ was recorded under $\mathrm{F}$ application on the $30^{\text {th }}$ and $45^{\text {th }}$ days in both sites. The highest mineral-N content was on the $45^{\text {th }}$ day after planting during SR16 season and on the $30^{\text {th }}$ day during LR17 season at Meru South. In Kandara, $\mathrm{NO}_{3}{ }^{-}-\mathrm{N}$ and $\mathrm{NH}_{4}{ }^{+}-\mathrm{N}$ were highest on the $45^{\text {th }}$ day and $30^{\text {th }}$ day, respectively, during SR16 season. During LR17 season, mineral-N was highest on the $30^{\text {th }}$ day in Kandara. The study highlights that minimal soil disturbance and organic inputs use or integration with fertilizers are feasible alternatives for improving soil fertility in the Nitisols of Central Highlands of Kenya.

\section{Introduction}

Soil nutrient management is a significant challenge for food production worldwide, sub-Saharan Africa (SSA) (Powlson et al., 2011) and in the Central Highlands of Kenya (Okeyo et al., 2014). Conventional soil tillage, indiscriminate use of agro-chemicals and continuous cropping significantly contribute to degradation in the physical, chemical and biological properties of the soil (Mariangela and Francesco, 2010; Wyngaard et al., 2012). Continuous soil tillage leads to degraded soil with low organic matter content and a fragile physical structure, which leads to low crop yields and low fertilizer use efficiency (Wang et al., 2007). Conversely, conservation tillage is known to improve soil fertility (Busari et al., 2015). Fertilization is also a critical factor in soil fertility restoration and maintenance (Cai et al., 2019). Limited application of soil external nutrients exacerbates soil degradation and jeopardizes soil's productivity in small-hold farms of SSA and 
the study area (Mucheru-Muna et al., 2014). Addition of soil nutrients through the application of manures, green manuring and intercropping improves organic carbon content which in turn enhances soil physical-chemical properties. Mandal et al. (2003) reported that green manure increased soil organic matter (SOM), total nitrogen concentration, bulk density and mean weight diameter aggregate, which increased crop growth. Inorganic fertilizers may also be applied however they accelerate decomposition of organic residues and potentially reduce aggregate stability (Mäder et al., 2002). In the Central Highlands of Kenya, continuous soil tillage coupled with low or non-use of soil fertility resources is a significant constraint to crop production (Kiboi et al., 2018). Use of readily available organic inputs (animal manure, biomass transfer) or their combination with mineral fertilizers could be used to build up soil organic carbon (SOC), meet the $\mathrm{N}$ requirements of annual crops, for example, Maize (Zea Mays L.) and improve soil physical properties in the study area.

Fertilization and conservation tillage systems are management practices that counteract soil degradation (Dalal et al., 2011). Conventional agriculture that uses extensive tillage without application of soil fertility inputs can cause degradation in soil chemical fertility (Tiritan et al., 2016). Conventional tillage depletes the chemical properties of soil (Mangalassery et al., 2015; Nivelle et al., 2016), while conservation tillage improves them (Divito, 2012). Conservation tillage has been reported to increase extractable $\mathrm{P}$, and exchangeable $\mathrm{Ca}, \mathrm{Mg}$, and $\mathrm{K}$, in the surface of the soil (Ismail et al., 1994). Application of soil fertility resources has also been shown to improve soil structure and chemical properties (Scotti et al., 2013). In their review, Mariangela and Francesco (2010) confirmed that numerous organic inputs applications enhanced soil available potassium, extractable phosphorous and organic carbon content. Ghosh et al. (2012) reported increased amounts of available N, P, and $\mathrm{K}$ in soils that received both organic and inorganic inputs. Leite et al. (2010) found that a combination of conservation tillage with organic inputs or with organic and inorganic fertilizers resulted in higher total $\mathrm{N}$ stocks. Thus, implementation of effective tillage and application of soil nutrient inputs can enhance soil properties.

Soil organic carbon, which can be affected by soil management practices, is a critical soil quality and health indicator, widely used as an index of SOM (Abraham, 2013). Soil organic matter in agricultural soils plays an essential role in the improvement of all soil properties and nutrient supply to crops (Yang et al., 2012). Continuous soil tillage which is widely practiced in the Central Highlands of Kenya (Kiboi et al., 2017), promotes soils carbon depletion and reduced productivity (Baker et al., 2007). Conversely, SOC content increases under minimum tillage compared to conventional tillage methods (Sun et al., 2011). Nitrogen fertilizers affect SOC levels but, the influence of this effect depends on management and the soil type (Jagadamma et al., 2007). Greater clay concentrations may stabilize the organic matter and improve productivity in finer textured soils (Bechtold and Naiman 2006). Many farmers in SSA and the study area have limited access and affordability of mineral fertilizers (Vanlauwe et al., 2011). Thus, the use of the available organic inputs would increase SOC content. According to Korodjouma et al. (2006), SOM increased on manured plots compared to non-manured plots. Garcia-franco et al. (2015) reported that reduced tillage combined with green manure increased SOC concentrations.

Nitrogen is an essential soil nutrient for crop growth. Conversely, it is often the most limiting nutrient for crop production (Lobell, 2007) in most agricultural systems. Some of the pathways that facilitate $\mathrm{N}$ lose include harvesting of crops, leaching, volatilization/gaseous losses, runoff and erosion (Rufino et al., 2006). Agricultural systems require surplus $\mathrm{N}$ additions to produce desired yields (Drinkwater, 2004). Changes in soil management practices such as tillage, litter input, and quality may significantly affect soil N content (Peichl and Leava, 2012). Tillage promotes soil organic $\mathrm{N}$ mineralization, which can lead to $\mathrm{N}_{2} \mathrm{O}$ production from nitrification and denitrification (Estavillo et al., 2002). Inorganic or organic fertilizers could be used to improve $\mathrm{N}$ availability to crops. However, much of the $\mathrm{N}$ in organic inputs is organically bound and must be mineralized to make it available to crops (Balkcom et al., 2009). Combination of mineral fertilizers and organic inputs accelerates $\mathrm{N}$ mineralization (Chivenge et al., 2011b). Ghosh et al. (2012) reported that soils receiving both inorganic and organic amendments consistently showed significantly higher amounts of available $\mathrm{N}$ due to the mineralization and release of $\mathrm{N}$ contained in the organics on their decomposition. Intercropping of cereal crops and legumes could also be used to increase potential $\mathrm{N}$ mineralization and available $\mathrm{N}$ (Sakala et al., 2000). To manage short and long-term $\mathrm{N}$ availability to crops from soil inputs, $\mathrm{N}$ release patterns need to be understood.

Soil physical properties such as aggregation and porosity indirectly influence plant growth through their effects on soil water content and mechanical impedance which affects root development and seedling emergence (Gomez et al., 2001). Excessive tillage may lead to reduced soil physical fertility. Conservation tillage has been found to improve aggregation (Mellek et al., 2010) and hydraulic conductivity (Abolanle et al., 2015) compared to tilled soils. Application of soil fertility resources such as animal manure, biomass transfer could also be used to increase soil physical fertility. Organic resources result in enhanced soil physical fertility, mainly by improving aggregate stability (Mariangela and Francesco, 2010). Mellek et al. (2010) found that dairy liquid manure led to a decrease in bulk density and increased aggregation. Application of manure and minimum tillage led to increased soil aggregation (Gicheru et al., 2004). However, the use of organic inputs in combination with mineral fertilizers and effective tillage practices for soil physical fertility improvement in the study area remains low leading to degraded soils which result in decreased crop yields. We hypothesized that minimum tillage combined with organic and inorganic soil fertility resources could be viable options that can produce beneficial effects on soil physical and chemical properties that can lead to soil fertility degradation arrest. Therefore, the objective of this study was to assess the effect of tillage practices and soil fertility resources on selected soil physical and chemical properties, SOC and mineral $\mathrm{N}$ dynamics under tropical sub-humid agro-ecological conditions.

\section{Materials and methods}

\section{Site description}

The experiment was conducted at Kangutu primary school farm $\left(00^{\circ} 98^{\prime} \mathrm{S}, 37^{\circ} 08^{\prime} \mathrm{E}\right)$ in Meru South sub-county and Kenya Agricultural and Livestock Organization (KALRO) farm $\left(00^{\circ}\right.$ $\left.20^{\prime} \mathrm{S}, 37^{\circ} 41^{\prime} \mathrm{E}\right)$ in Kandara sub-county. In both sites, the predominant soil type is Nitisols, a typically deep, weathered, welldrained, dusky red to dark reddish-brown, friable clay with acidic humic topsoil and moderate to high fertility (Jaetzold et al., 2007). The initial soil properties are shown in Table 1. Maize is the predominant annual crop in the two sub-counties. The rainfall pattern is bimodal in the two sub-counties with long rains season (LR) 
lasting from March to June and short rains season (SR) from late October to December, hence two cropping seasons per year (Jaetzold et al., 2007). The sub-counties are in the sub-humid region and receive average annual rainfall ranging from $400 \mathrm{~mm}$ to $1400 \mathrm{~mm}$ and a mean annual temperature of $20.7^{\circ} \mathrm{C}$ (Jaetzold et al., 2007).

During the study period, distinctions in cumulative rainfall amount and distribution in the cropping seasons were observed in each site (Figure 1). Meru South received total rainfall amounts of $879 \mathrm{~mm}$ during LR16, $385 \mathrm{~mm}$ during SR16, $341 \mathrm{~mm}$ during LR17, $571 \mathrm{~mm}$ during SR17 and $145 \mathrm{~mm}$ during off-seasons (Figure 1A). In Kandara, rainfall received during LR16 was 329 mm, $243 \mathrm{~mm}$ during SR16, $206 \mathrm{~mm}$ during LR17, $491 \mathrm{~mm}$ during SR17 and $95 \mathrm{~mm}$ during off-seasons (Figure 1B).

During the study period, distinctions in cumulative rainfall amount and distribution in the cropping seasons were observed in each site (Figure 1). Meru South received total rainfall amounts of $879 \mathrm{~mm}$ during LR16, $385 \mathrm{~mm}$ during SR16, $341 \mathrm{~mm}$ during LR17, $571 \mathrm{~mm}$ during SR17 and $145 \mathrm{~mm}$ during off-seasons (Figure 1A). In Kandara, rainfall received during LR16 was 329 mm, $243 \mathrm{~mm}$ during SR16, $206 \mathrm{~mm}$ during LR17, $491 \mathrm{~mm}$ during SR17 and $95 \mathrm{~mm}$ during off-seasons (Figure 1B).

Both sites experienced meteorological droughts and dry spells in all cropping seasons. Meru South site experienced a meteorological drought of 33 days and dry spells of 16 and 13 days while Kandara site had a meteorological drought of 31 and dry spells of 18,10 and 24 days during the LR16 season. A dry spell of 10 days was experienced in Meru South at the beginning of the SR16 season and a meteorological drought of 31 days towards the end of the season (Figure 1A). In Kandara, there were dry spells of 17 and 14 days at the onset of the SR16 season and a meteorological drought of 36 days towards the end of the season (Figure 1B). During LR17 season, Meru South had a dry spell of 21 days at the beginning of the season and a meteorological drought of 31 days towards the end of the season while Kandara site experienced dry spells' of 17, 10 and 16 days and a meteorological drought of 31 days at the end of the season. In the SR17 season, Meru South experienced dry spells' of 17, 15 and 27 days while Kandara had two dry spells of 10 days each and a meteorological drought of 43 days (Figure 1).

\section{Field experiments}

The experimental design was a split-plot implemented in a randomized complete block arrangement with four replications (Kiboi et al., 2018). Tillage was the main factor at two levels (minimum and conventional tillage) while soil fertility resources were the sub-factors at six levels (sole mineral fertilizer, crop residues + mineral fertilizer, crop residues +mineral fertilizer + animal manure, crop residues + Tithonia diversifolia + phosphate rock (Minjingu), crop residues + animal manure+ legume intercrop (Dolichos lablab) and crop residues + Tithonia diversifolia + animal manure and a control treatment (no input applied). Both tillage and soil fertility resources factors resulted in 14 combinations/treatments. Animal manure and Tithonia diversifolia were incorporated into the soil two weeks to the onset of the cropping season, during land preparation. Incorporation in the minimum tillage plots was limited to the planting rows. Maize (Zea Mays L.) was the test crop. Soil fertility resources were applied to give an equivalent amount of $60 \mathrm{~kg} \mathrm{~N} \mathrm{ha}^{-1}$ to meet maize nutrient requirements in the two study areas (FURP, 1987). Maize crop residue was uniformly $\left(5 \mathrm{Mg} \mathrm{ha}^{-1}\right)$ applied in five treatments under each tillage practice after crop emergence. Soil organic carbon was determined during LR16 and SR17 season while mineral $\mathrm{N}$ was determined during the SR16 and LR17 seasons.

\section{Soil sampling}

Soils were sampled during the trials' establishment (LR16 season) and at the end of the study period (LR17 season). For the physical characteristics (texture, bulk density, hydraulic conductivity, and aggregate stability), undisturbed soils were sampled at 0-5 $\mathrm{cm}$ depth using core rings measuring $50 \mathrm{~mm}$ by $50 \mathrm{~mm}$, diameter and height, respectively. Composite samples for selected soil chemical properties ( $\mathrm{pH}$ water, total $\mathrm{N}$, available $\mathrm{P}$, potassium, and exchangeable $\mathrm{Ca}$ and $\mathrm{Mg}$ ) were sampled from each experimental plot at 0-20 cm depth using Edelman auger. For soil organic carbon

Table 1. Soil properties $(0-20 \mathrm{~cm})$ at Meru South and Kandara sub-Counties study sites (Source Kiboi et al., 2018).

\begin{tabular}{lcc} 
Parameter & Meru South & Kandara \\
Soil texture & & \\
$\quad$ Clay (\%) & 70 & 80 \\
Silt (\%) & 16 & 10 \\
Sand (\%) & 14 & 10 \\
Textural class & Clay soil & Clay soil \\
pH 4.85 & 5.49 & \\
Total N (\%) & 0.14 & 0.14 \\
\hline Total C (\%) & 1.48 & 1.38 \\
Available P $(\mathrm{g} / \mathrm{kg})$ & 0.02 & 0.02 \\
\hline Exch. ${ }^{*} \mathrm{~K}+(\mathrm{cmol}+/ \mathrm{kg})$ & 0.45 & 1.15 \\
Exch. Ca+ $(\mathrm{cmol}+\mathrm{kg})$ & 2.53 & 4.15 \\
\hline Exch. $\mathrm{Mg}+(\mathrm{cmol}+/ \mathrm{kg})$ & 1.17 & 1.38 \\
\hline
\end{tabular}

*Exch, exchangeable.
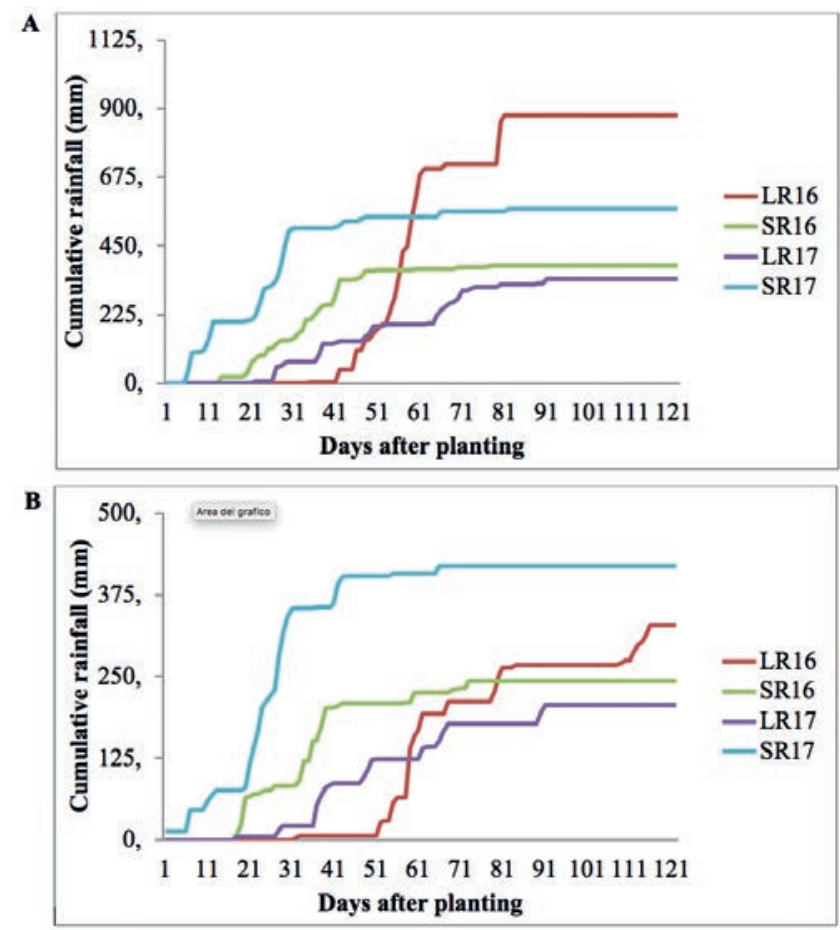

Figure 1. Cumulative rainfall amount received in Meru South (A) and Kandara (B) experiment sites during long rains 2016, short rains 2016, long rains 2017 and short rains 2017 seasons. 
samples, undisturbed soil sampling was done using Eijkelkamp Gouge Auger at depths of 0-5 cm, 5-10 cm, 10-20 cm, and 20-40 $\mathrm{cm}$.

\section{Mineral nitrogen}

To determine mineral $\mathrm{N}$ content $\left(\mathrm{NO}_{3}{ }^{-}-\mathrm{N}\right.$ and $\left.\mathrm{NH}_{4}{ }^{+}-\mathrm{N}\right)$, soil samples were collected at 0-20 $\mathrm{cm}$ depth using Eijkelkamp Gouge Auger during planting (0), 30, 45, 60, and 90 days after sowing. Sampling was done in between plants within the rows since the incorporation of the soil fertility resources in the minimum tillage plots was limited to planting rows. The soil samples were transported to the laboratory in cool boxes and refrigerated at $4{ }^{\circ} \mathrm{C}$ pending processing. Moist samples were passed through $8 \mathrm{~mm}$ sieve, and subsamples of $30 \mathrm{~g}$ picked. Crop residues and other debris $(>2$ $\mathrm{mm}$ ) were manually removed from the subsamples. A $15 \mathrm{~g}$ portion of the subsample was oven-dried at $105^{\circ} \mathrm{C}$ to gravimetrically determine soil moisture content. The remaining $15 \mathrm{~g}$ was extracted with $50 \mathrm{ml} 0.5 \mathrm{M} \mathrm{KCL}$ by shaking on a reciprocal shaker for 1 hour and filtered through a Whatman No. 42 ashless filter paper.

\section{Laboratory analyses}

Laboratory analyses (both physical and chemical parameters for soil characterization) were done following the standard methods of soil analysis described by Ryan et al. (2001). Soil pH water (1:1, soil: water) was measured using $\mathrm{pH}$ meter; nitrogen by the Kjeldahl method, available phosphorus by Mehlich 3 method (Mehlich, 1984); potassium by a flame photometer and exchangeable calcium and magnesium by atomic absorption spectrophotometry and organic carbon by modified Walkley and Black wet oxidation method.

Soil texture by hydrometer method, bulk density was determined gravimetrically; hydraulic conductivity by constant-head method (Klute and Dirksen, 1986) and aggregate stability by Rotary dry sieving method (Lyles et al., 1970). The mean weight diameter was calculated using Eq. (1) Kemper and Rosenau (1986).

$M W D=\sum_{i=1}^{8} \bar{x}_{i} w_{i}$

where $M W D$ is mean weight diameter $(\mathrm{mm}), w_{i}$ is total weight fraction of aggregates in the size class $i$ with a diameter $\bar{x}_{i}$.

\section{Statistical analyses}

The data were subjected to analysis of variance (ANOVA) using the Mixed Procedure Model in SAS 9.3 software (SAS Institute, 2011) to obtain an F value of the model effect. Differences between treatment means were examined using Tukey's Kramer HSD (Honestly significant difference) at $\mathrm{P}=0.05$.

\section{Results}

\section{Soil physical properties}

The soil physical properties (soil texture, bulk density, aggregate stability, and hydraulic conductivity) were not significantly different between the treatment plots at the beginning of the experiment period in both sites (Table 2). At the end of the study period, bulk density was not significantly different between the treatments in Meru South. Aggregate stability declined in all the treatments in Meru South; nevertheless, it was significantly $(\mathrm{P}=0.01)$ higher under RML by $24 \%$ compared with the control (Table 2). Hydraulic conductivity declined under all the treatments except RF at the end of the study period.

In Kandara, bulk density was significantly higher under mini-

Table 2. Soil physical properties in Meru South and Kandara study sites at the beginning (LR16) and end (LR17) of the study period.

\begin{tabular}{|c|c|c|c|c|c|c|c|c|c|c|c|c|}
\hline \multirow{2}{*}{$\begin{array}{l}\text { Treatment } \\
\text { Tillage }\end{array}$} & \multicolumn{2}{|c|}{$\begin{array}{c}\mathrm{BD} \\
\mathrm{g} \mathrm{cm}^{-3}\end{array}$} & \multicolumn{2}{|c|}{$\begin{array}{c}\text { MWD } \\
\mathrm{mm}\end{array}$} & \multicolumn{2}{|c|}{$\begin{array}{l}\mathrm{K}_{\text {sat }} \\
\mathrm{cm}\end{array}$} & \multicolumn{2}{|c|}{$\begin{array}{c}\text { BD } \\
\mathrm{hr}^{-1}\end{array}$} & \multicolumn{2}{|c|}{$\begin{array}{l}\text { MWD } \\
\mathrm{g} \mathrm{cm}^{-3}\end{array}$} & \multicolumn{2}{|c|}{$\begin{array}{c}\text { Ksat } \\
\text { mm }\end{array}$} \\
\hline & LR16 & LR17 & LR16 & LR17 & LR16 & LR17 & LR16 & LR17 & LR16 & LR17 & LR16 & LR17 \\
\hline $\mathrm{D}_{15}$ & $0.93^{\mathrm{a}}$ & $0.93^{\mathrm{a}}$ & $1.07^{\mathrm{a}}$ & $0.61^{\mathrm{a}}$ & $16.57^{\mathrm{a}}$ & $13.83^{\mathrm{a}}$ & $1.05^{\mathrm{a}}$ & $1.01^{\mathrm{b}}$ & $0.70^{\mathrm{a}}$ & $0.85^{\mathrm{a}}$ & $18.21^{\mathrm{a}}$ & $15.06^{\mathrm{a}}$ \\
\hline $\mathrm{D}_{0}$ & $0.96^{\mathrm{a}}$ & $0.95^{\mathrm{a}}$ & $1.04^{\mathrm{a}}$ & $0.56^{\mathrm{a}}$ & $17.06^{\mathrm{a}}$ & $16.56^{\mathrm{a}}$ & $1.07^{\mathrm{a}}$ & $1.05^{\mathrm{a}}$ & $0.71^{\mathrm{a}}$ & $0.80^{\mathrm{a}}$ & $15.70^{\mathrm{a}}$ & $13.60^{\mathrm{a}}$ \\
\hline \multicolumn{13}{|c|}{ Soil fertility resources } \\
\hline Control & $0.99^{\mathrm{a}}$ & $0.94^{\mathrm{a}}$ & $1.02^{\mathrm{a}}$ & $0.55^{\mathrm{bc}}$ & $15.09^{\mathrm{a}}$ & $13.79^{\mathrm{a}}$ & $1.04^{\mathrm{a}}$ & $1.05^{\mathrm{a}}$ & $0.70^{\mathrm{a}}$ & $0.87^{\mathrm{ab}}$ & $21.87^{\mathrm{a}}$ & $14.26^{\mathrm{b}}$ \\
\hline $\mathrm{F}$ & $0.95^{\mathrm{a}}$ & $0.96^{\mathrm{a}}$ & $1.12^{\mathrm{a}}$ & $0.48^{c}$ & $12.77^{\mathrm{a}}$ & $10.29^{\mathrm{a}}$ & $1.14^{\mathrm{a}}$ & $1.04^{\mathrm{a}}$ & $0.71^{\mathrm{a}}$ & $0.86^{\mathrm{ab}}$ & $13.41^{\mathrm{a}}$ & $11.55^{b}$ \\
\hline $\mathrm{RF}$ & $0.97^{\mathrm{a}}$ & $0.91^{\mathrm{a}}$ & $1.04^{\mathrm{a}}$ & $0.64^{\mathrm{ab}}$ & $13.95^{\mathrm{a}}$ & $20.50^{\mathrm{a}}$ & $1.05^{\mathrm{a}}$ & $1.05^{\mathrm{a}}$ & $0.72^{\mathrm{a}}$ & $0.78^{b}$ & $17.80^{\mathrm{a}}$ & $15.78^{\mathrm{ab}}$ \\
\hline RFM & $0.95^{\mathrm{a}}$ & $0.99^{\mathrm{a}}$ & $1.05^{\mathrm{a}}$ & $0.58^{\mathrm{abc}}$ & $18.61^{\mathrm{a}}$ & $15.64^{\mathrm{a}}$ & $1.05^{\mathrm{a}}$ & $1.04^{\mathrm{a}}$ & $0.68^{\mathrm{a}}$ & $0.97^{a}$ & $17.07^{\mathrm{a}}$ & $11.09^{b}$ \\
\hline RML & $0.92^{\mathrm{a}}$ & $0.93^{\mathrm{a}}$ & $10.4^{\mathrm{a}}$ & $0.68^{\mathrm{a}}$ & $17.99^{a}$ & $13.92^{\mathrm{a}}$ & $1.03^{\mathrm{a}}$ & $1.03^{\mathrm{a}}$ & $0.85^{\mathrm{a}}$ & $0.76^{\mathrm{b}}$ & $15.73^{\mathrm{a}}$ & $22.46^{\mathrm{a}}$ \\
\hline RTiM & $0.94^{\mathrm{a}}$ & $0.94^{\mathrm{a}}$ & $1.09^{\mathrm{a}}$ & $0.63^{\mathrm{ab}}$ & $20.64^{a}$ & $13.77^{a}$ & $1.09^{\mathrm{a}}$ & $1.00^{\mathrm{a}}$ & $0.65^{\mathrm{a}}$ & $0.79^{\mathrm{b}}$ & $16.41^{\mathrm{a}}$ & $13.97^{\mathrm{b}}$ \\
\hline RTiP & $0.93^{\mathrm{a}}$ & $0.95^{\mathrm{a}}$ & $1.01^{\mathrm{a}}$ & $0.59^{\mathrm{ab}}$ & $18.66^{\mathrm{a}}$ & $18.45^{\mathrm{a}}$ & $1.04^{\mathrm{a}}$ & $1.03^{\mathrm{a}}$ & $0.64^{\mathrm{a}}$ & $0.78^{b}$ & $16.39^{\mathrm{a}}$ & $11.24^{b}$ \\
\hline \multicolumn{13}{|l|}{ Effect } \\
\hline Tillage & ns & ns & ns & ns & ns & ns & ns & 0.02 & ns & ns & ns & ns \\
\hline SFR & ns & ns & ns & 0.05 & ns & ns & ns & ns & ns & 0.05 & ns & 0.04 \\
\hline Tillage * SFR & ns & ns & ns & $\mathrm{ns}$ & ns & ns & ns & ns & ns & $\mathrm{ns}$ & ns & $\mathrm{ns}$ \\
\hline
\end{tabular}

Tr, treatment; $D_{15}$, conventional tillage; $D_{0}$, minimum tillage; LR16, long rains 2016 season; LR17, long rains 2017 season; F, mineral fertiliser, RF, crop residue + mineral fertiliser; RFM, crop residue + mineral fertiliser + animal manure; RML, crop residue + animal manure + legume intercrop; RTiM, crop residue + Tithonia diversifolia + animal manure, RTiP, crop residue + Tithonia diversifolia + phosphate rock; ns, not significant; SFR, soil fertility resources. a,bDifferent letters indicate significant differences of the post hoc Tukey's HSD test performed in case effects of the model was significant ( $\mathrm{P} \leq 0.05)$. 
mum tillage $\left(D_{0}\right)$ by $4 \%$ compared with conventional tillage $\left(D_{15}\right)$. There was an increase in aggregate stability at the end of the study period under all the implemented treatments but no significant difference between the treatments compared with the control (Table 2). Hydraulic conductivity significantly $(\mathrm{P}=0.04)$ increased under RML by $57 \%$ compared with the control at the end of the study period (Table 2). The interactions had no significant influence on soil physical properties at the end of the study period in both sites (Table 2). Generally, soils in Kandara had a higher bulk density (ranging from 1.00 to $1.14 \mathrm{~g} \mathrm{~cm}^{-3}$ ) than in Meru South site (ranging from 0.93 to $0.99 \mathrm{~g} \mathrm{~cm}^{-3}$ ) (Table 2).

On average, bulk density and hydraulic conductivity were not significantly different between the soil fertility resources compared with the control at the end of the study period in both sites (Table 3). Aggregate stability (MWD) was significantly higher under treatments with sole organic inputs (Org) by 19\% compared with the control in Meru South site but was not significantly influenced by the SFR in Kandara site (Table 3).

\section{Soil chemical properties}

Soil $\mathrm{pH}$, total $\mathrm{N}$, available $\mathrm{P}, \mathrm{K}, \mathrm{Ca}$ and $\mathrm{Mg}$ were not statisti- cally different between the treatment plots at the beginning of the study in both sites (LR16) (data not shown). At the end of the study period, tillage had no significant influence on the measured soil chemical properties in both sites (Table 4). Conversely, soil pH, $\mathrm{P}$, $\mathrm{K}$ and $\mathrm{Ca}$ were significantly influenced under soil fertility resources (SFR) at both sites. In Meru South, soil $\mathrm{pH}$ was significantly higher under RTiM and RML by $8 \%$ compared with the control (Table 4). Available P was significantly higher under RtiP, RFM, RF, and F by 223, 204, 153 and $139 \%$ compared with the control. Still, in Meru South, K was significantly higher under RtiM, RML, and RtiP by 164, 96 and 78\% compared with the control. Calcium significantly increased under RtiM, RML, RFM, and RtiP by 17, 14, 7 and 5\% compared with the control (Table 4). Total $\mathrm{N}$ and $\mathrm{Mg}$ were not statistically different between SFRs at the end of the study period in Meru South. The interactions had no significant influence on the soil chemical properties at Meru South site. In Kandara, soil pH significantly increased under RtiM, RML, RFM, and RtiP by 17, 14, 7 and 5\% respectively, compared with the control (Table 4). Total N was not significantly different between SFR in Kandara. Phosphorous was significantly $(\mathrm{P}=0.002)$ influenced under all the SFR compared with the control

Table 3. Average of soil physical properties under soil fertility resources in Meru South and Kandara study sites at the end of study period (LR17).

\begin{tabular}{|c|c|c|c|c|c|c|}
\hline $\begin{array}{l}\text { Treatment } \\
\text { SFR }\end{array}$ & $\begin{array}{c}\mathrm{BD} \\
\mathrm{g} \mathrm{cm}^{-3}\end{array}$ & $\begin{array}{c}\text { eru Sot } \\
\text { MWD } \\
\text { mm }\end{array}$ & $\begin{array}{l}\text { Ksat } \\
\mathrm{cm} \mathrm{hr}^{-1}\end{array}$ & $\begin{array}{c}\mathrm{BD} \\
\mathrm{g} \mathrm{cm}^{-3}\end{array}$ & $\begin{array}{c}\text { Kandara } \\
\text { MWD } \\
\text { mm }\end{array}$ & $\begin{array}{c}\text { Ksat } \\
\mathrm{cm} \mathrm{hr}^{-1}\end{array}$ \\
\hline Control & $0.94^{\mathrm{a}}$ & $0.54^{\mathrm{b}}$ & $13.78^{\mathrm{a}}$ & $1.05^{\mathrm{a}}$ & $0.86^{\mathrm{a}}$ & $14.25^{\mathrm{ab}}$ \\
\hline Fert & $0.93^{\mathrm{a}}$ & $0.55^{\mathrm{b}}$ & $15.39^{\mathrm{a}}$ & $1.04^{\mathrm{a}}$ & $0.82^{\mathrm{a}}$ & $13.66^{\mathrm{ab}}$ \\
\hline Fert + Org & $0.96^{\mathrm{a}}$ & $0.58^{\mathrm{ab}}$ & $17.04^{\mathrm{a}}$ & $1.03^{\mathrm{a}}$ & $0.87^{\mathrm{a}}$ & $11.16^{b}$ \\
\hline Org & $0.93^{\mathrm{a}}$ & $0.65^{\mathrm{a}}$ & $13.84^{\mathrm{a}}$ & $1.01^{\mathrm{a}}$ & $0.77^{\mathrm{a}}$ & $18.21^{\mathrm{a}}$ \\
\hline Pvalue & ns & 0.05 & $\mathrm{~ns}$ & ns & ns & ns \\
\hline
\end{tabular}

SFR, soil fertility resources; Control, no fertiliser; Fert, mineral fertiliser; Fert+Org, mineral fertiliser plus organic inputs; Org, organic inputs; BD, bulk density; MWD, aggregate mean weight diameter, Ksat, hydraulic conductivity, ns, not significant; ns, not significant. a,bSame superscript letters in the same column denote no significant difference between the treatment means at a given site at $\mathrm{P}=0.05$.

Table 4. Soil chemical properties in Meru South and Kandara sites at the end of study period (LR17).

\begin{tabular}{|c|c|c|c|c|c|c|c|c|c|c|c|c|}
\hline \multirow{3}{*}{$\begin{array}{l}\text { Treatment } \\
\text { lillage } \\
\mathrm{D}_{15}\end{array}$} & \multirow{3}{*}{$\begin{array}{c}\mathrm{pH} \\
4.96^{\mathrm{a}}\end{array}$} & \multicolumn{5}{|c|}{ Meru South } & \multirow{2}{*}{ pH } & \multirow[b]{2}{*}{$\begin{array}{c}\text { Total N } \\
\%\end{array}$} & \multicolumn{4}{|c|}{ Kandara } \\
\hline & & Total N & $\stackrel{P}{g / k g}$ & \multicolumn{3}{|c|}{ Exchangeable cmol+/kg } & & & $\stackrel{P}{\rho / k \sigma}$ & $\begin{array}{c}\mathrm{K} \\
\text { Exchan }\end{array}$ & $\mathrm{Ca}$ & $\begin{array}{l}\mathrm{Mg} \\
0 \mathrm{l}+\mathrm{kg}\end{array}$ \\
\hline & & $0.17^{\mathrm{a}}$ & $28.33^{\mathrm{a}}$ & $0.39^{\mathrm{a}}$ & $4.98^{\mathrm{a}}$ & $0.15^{\mathrm{a}}$ & $4.98^{\mathrm{a}}$ & $0.15^{\mathrm{a}}$ & $31.92^{\mathrm{a}}$ & $1.04^{\mathrm{a}}$ & $2.57^{\mathrm{a}}$ & $2.13^{\mathrm{a}}$ \\
\hline $\mathrm{D}_{0}$ & $4.98^{\mathrm{a}}$ & $0.17^{\mathrm{a}}$ & $30.37^{\mathrm{a}}$ & $0.46^{\mathrm{a}}$ & $4.89^{\mathrm{a}}$ & $0.16^{\mathrm{a}}$ & $4.89^{\mathrm{a}}$ & $0.16^{\mathrm{a}}$ & $29.52^{\mathrm{a}}$ & $1.03^{\mathrm{a}}$ & $2.52^{\mathrm{a}}$ & $2.02^{\mathrm{a}}$ \\
\hline \multicolumn{13}{|c|}{ Soil fertility resources } \\
\hline Control & $4.89^{\mathrm{bc}}$ & $0.16^{\mathrm{a}}$ & $13.75^{c}$ & $0.28^{\mathrm{dc}}$ & $4.69^{c}$ & $0.15^{\mathrm{a}}$ & $4.69^{c}$ & $0.15^{\mathrm{a}}$ & $16.25^{c}$ & $0.82 \mathrm{e}$ & $2.44^{\mathrm{b}}$ & $1.55^{\mathrm{c}}$ \\
\hline $\mathrm{F}$ & $4.51^{\mathrm{d}}$ & $0.16^{\mathrm{a}}$ & $32.97^{\mathrm{b}}$ & $0.23^{\mathrm{d}}$ & $4.49 \mathrm{~cd}$ & $0.16^{\mathrm{a}}$ & $4.49^{c d}$ & $0.16^{\mathrm{a}}$ & $27.50^{\mathrm{b}}$ & $0.78 \mathrm{e}$ & $2.39^{\mathrm{b}}$ & $1.96^{\mathrm{b}}$ \\
\hline $\mathrm{RF}$ & $4.72^{\text {cd }}$ & $0.16^{\mathrm{a}}$ & $34.81^{\mathrm{ab}}$ & $0.28^{\mathrm{dc}}$ & $4.48^{\mathrm{d}}$ & $0.15^{\mathrm{a}}$ & $4.48^{\mathrm{d}}$ & $0.15^{\mathrm{a}}$ & $35.00^{\mathrm{ab}}$ & $0.78 \mathrm{e}$ & $2.36^{\mathrm{b}}$ & $2.10^{\mathrm{ab}}$ \\
\hline RFM & $4.93^{\mathrm{bc}}$ & $0.17^{\mathrm{a}}$ & $41.87^{a b}$ & $0.43^{b c}$ & $5.04^{b}$ & $0.16^{\mathrm{a}}$ & $5.04^{\mathrm{b}}$ & $0.16^{\mathrm{a}}$ & $40.63^{\mathrm{a}}$ & $1.04^{\mathrm{d}}$ & $2.46^{\mathrm{b}}$ & $2.28^{\mathrm{a}}$ \\
\hline RML & $5.28^{\mathrm{a}}$ & $0.17^{\mathrm{a}}$ & $20.00^{c}$ & $0.55^{\mathrm{b}}$ & $5.39^{\mathrm{a}}$ & $0.17^{\mathrm{a}}$ & $5.39^{\mathrm{a}}$ & $0.17^{\mathrm{a}}$ & $33.13^{\mathrm{ab}}$ & $1.28^{b}$ & $2.70^{\mathrm{ab}}$ & $2.27^{\mathrm{a}}$ \\
\hline RtiM & $5.29^{a}$ & $0.18^{a}$ & $17.50^{c}$ & $0.74^{\mathrm{a}}$ & $5.53^{\mathrm{a}}$ & $0.16^{\mathrm{a}}$ & $5.53^{\mathrm{a}}$ & $0.16^{\mathrm{a}}$ & $28.61^{\mathrm{b}}$ & $1.41^{\mathrm{a}}$ & $2.88^{\mathrm{a}}$ & $2.23^{\mathrm{ab}}$ \\
\hline RtiP & $5.16^{\mathrm{ab}}$ & $0.18^{\mathrm{a}}$ & $44.54^{\mathrm{a}}$ & $0.50^{\mathrm{b}}$ & $4.93^{b}$ & $0.15^{\mathrm{a}}$ & $4.93^{b}$ & $0.15^{\mathrm{a}}$ & $33.96^{\mathrm{ab}}$ & $1.15^{c}$ & $2.58^{\mathrm{ab}}$ & $2.15^{\mathrm{ab}}$ \\
\hline \multicolumn{13}{|c|}{ Effects } \\
\hline Tillage & ns & ns & ns & $\mathrm{ns}$ & ns & ns & ns & ns & ns & ns & $\mathrm{ns}$ & ns \\
\hline SFR & $<.0001$ & ns & $<.0001$ & $<.0001$ & $<.0001$ & ns & $<.0001$ & ns & 0.002 & $<.0001$ & 0.05 & $<.0001$ \\
\hline Tillage * SFR & ns & ns & ns & ns & ns & ns & ns & ns & $\mathrm{ns}$ & ns & ns & 0.02 \\
\hline
\end{tabular}

$\mathrm{D}_{15}$, Conventional tillage; $\mathrm{D}_{0}$, Minimum tillage; $\mathrm{F}$, mineral fertiliser; $\mathrm{RF}$, crop residue + mineral fertiliser; $\mathrm{RFM}$, crop residue + mineral fertiliser + animal manure; RML , crop residue + animal manure +legume intercrop; RTiM, crop residue + Tithonia diversifolia + animal manure; RTiP, crop residue + Tithonia diversifolia + phosphate rock; ns, not significant; SFR, soil fertility resources. a,b,c,different letters indicate significant differences of the post hoc Tukey's HSD test performed in case effects of the model was significant $(\mathrm{P} \leq 0.05)$. 
(Table 4). Potassium significantly increased under RtiM, RML, RtiP, and RFM by 72, 56, 40 and 27\% compared with the control. Calcium was only significantly higher under RtiM compared with the control (Table 4). Application of RML, RFM and RtiP showed slightly high $\mathrm{Ca}$ content compared with the control in Kandara. Magnesium was significantly different under RFM, RML, RtiM, RtiP, RF and $\mathrm{F}$ by $47,46,43,38,35$ and $26 \%$ compared with the control. On average, the application of sole mineral fertilizer led to lower $\mathrm{pH}$ compared with the control at both sites (Table 5). In Meru South, soil $\mathrm{pH}$ significantly increased $(\mathrm{p}<.0001)$ under sole organic treatments (Org) by $10 \%$ in Meru South compared with the control (Table 5). Total $\mathrm{N}$ was significantly higher under the integration of fertilizer and organic inputs (Fert + Org) compared with the control in Meru South. Phosphorous was significantly higher under Fert+ Org treatment by $214 \%$ while Ca significantly increased under Org and Fert+ Org by 101 and $76 \%$, respectively compared with the control in Meru South.

In Kandara, $\mathrm{pH}$ significantly increased $(\mathrm{P}<0.0001)$ under Org $17 \%$ compared with the control. Phosphorous was significantly higher under Fert+ Org treatment by $129 \%$ compared with the control (Table 5). While Ca significantly increased under Org by $15 \%$ compared with the control, magnesium significantly increased under Org, Fert+ Org and Fert by 46, 43 and 32\% compared with the control in Kandara (Table 5).

\section{Soil organic carbon}

At the beginning of the study, there were no significant differences in soil organic carbon (SOC) between the treatment plots at both sites (data not shown). At the end of the study (four cropping seasons), tillage had no significant influence on SOC in all the sampled depths' at Meru South site. However, $\mathrm{D}_{0}$ showed slightly higher values compared to $\mathrm{D}_{15}$ (Table 6), but these changes were not significant (Figure 2A). Soil fertility resources significantly influenced SOC at Meru South site in the sampled depths' except in the $5-10 \mathrm{~cm}$ depth. This was also indicated by the recorded significant changes (Figures 2A and 3A-B). Application of RTiM led to the highest SOC increase in all depths' at Meru South site (Table 6). In the $0-5 \mathrm{~cm}$ depth, SOC significantly increased under RTiM, RTiP, RML, RF, and RFM by 47, 35, 33, 33 and 29\% compared with the control in Meru South (Table 6). Despite the SFRs' not significantly influencing SOC in the $5-10 \mathrm{~cm}$ depth in Meru South, there was a similar trend with that observed in the $0-5 \mathrm{~cm}$ depth (Table 6). In the 10-20 and 20-40 cm depths' all the SFRs' significantly increased SOC compared with the control. SOC changes under control showed a decline in the first three sampled depths at Meru South site (Figures 2A-B and 3A).

In Kandara, $\mathrm{D}_{0}$ significantly $(\mathrm{P}=0.02)$ increased $\mathrm{SOC}$ by $6 \%$ compared with $\mathrm{D}_{15}$ at $0-5 \mathrm{~cm}$ depth (Table 6 and Figure 2A). Minimum tillage also showed slightly higher SOC values in the other depths compared to conventional tillage in Kandara. Soil fertility resources significantly influenced SOC in the first two sampled depths' and showed an increasing trend in the last two sampled depths' compared with the control (Table 6). In the 0-5 cm depth, SOC significantly increased under RTiP and RML by $11 \%$ and under RML by $13 \%$ in the $5-10 \mathrm{~cm}$ depth compared with the control. The control showed a decrease in SOC in the last two sampled depths in Kandara site (Figure 3A and B). The interactions had no significant influence on SOC in all sampled depths in both study sites (Table 6).

\section{Soil mineral nitrogen}

The bulk of soil mineral $\mathrm{N}$ content found in the soil on all sam-
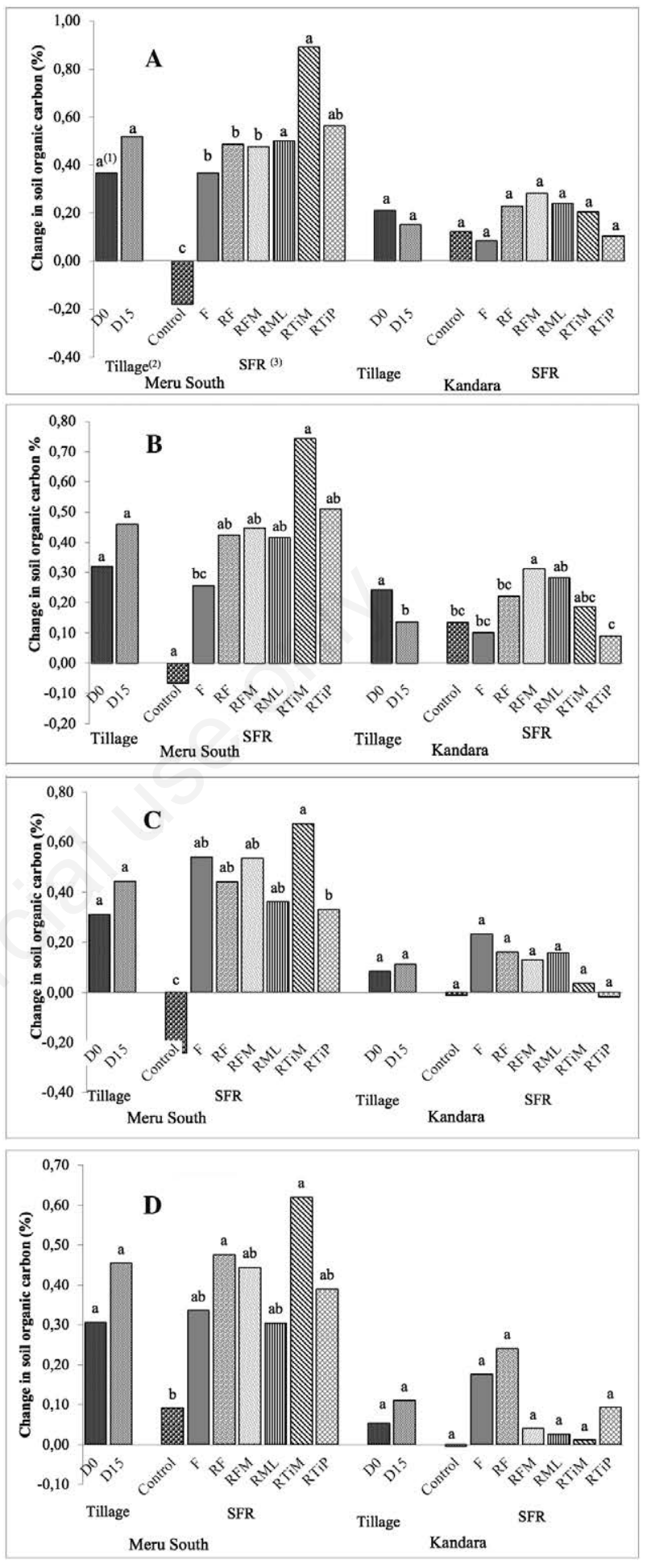

Figure 2. Changes in soil organic carbon (\%) in the A) 0-5, B) 510, C) $10-20$, D) $20-40 \mathrm{~cm}$ depth' at Meru South and Kandara sites. ${ }^{1)}$ Different letters indicate significant differences in the post hoc Tukey's HSD test performed in case effects of the model was significant $(\mathbf{P} \leq \mathbf{0 . 0 5})$. (2) Tillage abbreviations $D_{15}=$ Conventional tillage, $\mathrm{D}_{0}=$ Minimum tillage. ${ }^{(3)} \mathrm{SFR}=$ Soil fertility resources abbreviations, Control=No input, $\mathrm{F}=$ Mineral fertiliser, $\mathrm{RF}=\mathrm{Crop}$ residue + mineral fertiliser, $\mathrm{RFM}=\mathrm{Crop}$ residue + mineral fertiliser + animal manure, $\mathrm{RML}=\mathrm{Crop}$ residue + animal manure +legume intercrop, $\mathrm{RTiM}=\mathrm{Crop}$ residue + Tithonia diversifolia + animal manure, $\mathrm{RTiP}=\mathrm{Crop}$ residue + Tithonia diversifolia + phosphate rock. 


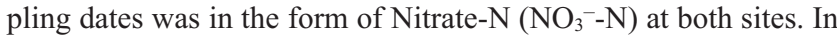
Meru South, $\mathrm{NO}_{3}{ }^{-}-\mathrm{N}$ was significantly different under tillage at planting and 45 days after planting during SR16 season (Figure $3 \mathrm{~A})$. At planting $\mathrm{NO}_{3}{ }^{-}-\mathrm{N}$ was significantly $(\mathrm{P}<0.0001)$ higher under minimum tillage $\left(\mathrm{D}_{0}\right)$ by $74 \%$ compared with the conventional tillage $\left(\mathrm{D}_{15}\right)$. On the $45^{\text {th }}$ day, $\mathrm{NO}_{3}{ }^{-}-\mathrm{N}$ significantly $(\mathrm{P}=0.02)$ decreased under $\mathrm{D}_{0}$ by $77 \%$ compared with the $\mathrm{D}_{15}$ in Meru South. Ammonium-N content was not significantly influenced by tillage during SR16 season in Meru South (Figure 3B). From the $30^{\text {th }}$ day after planting, mineral $\mathrm{N}$ was higher under $\mathrm{D}_{15}$ compared with the $\mathrm{D}_{0}$ (Figure $3 \mathrm{~A}$ and $4 \mathrm{~B}$ ). Under soil fertility resources, soil $\mathrm{NO}_{3}{ }^{-}-\mathrm{N}$ was significantly different at planting, 30 and $90^{\text {th }}$ day after planting during SR16 season in Meru South. On the $30^{\text {th }}$ day, $\mathrm{NO}_{3}{ }^{-}-\mathrm{N}$ was significantly $(\mathrm{P}=0.003$ ) higher under mineral fertilizer $(\mathrm{F})$ by $39 \%$, compared with the control (C) (Figure 4A). On the $90^{\text {th }}$ day, $\mathrm{NO}_{3}{ }^{-}-\mathrm{N}$ was significantly $(\mathrm{P}=0.02)$ different between the various SFRs but not significantly higher than the control. Ammonium-N content under SFRs was significantly $(\mathrm{P}=0.03)$ different on the $90^{\text {th }}$ day during SR16 season. It was significantly higher under RTiP and RTiM by 23 and 16\% respectively, compared with the control
(Figure 4B). The interactions significantly influenced $\mathrm{NO}_{3}{ }^{-}-\mathrm{N}$ on the $30^{\text {th }}(\mathrm{P}<0.0001)$ and $90^{\text {th }}(\mathrm{P}=0.03)$ day after planting at Meru South site during SR16 season (Table 7). On the $30^{\text {th }}$ day, only minimum tillage* fertilizer $\left(\mathrm{D}_{0} * \mathrm{~F}\right)$ was significantly higher than the control and greatly decreased on the $45^{\text {th }}$ day (Table 7). Nitrate-N content was least under all the interactions on the $90^{\text {th }}$ day during SR16 season with the $\mathrm{D}_{15} * \mathrm{RFM}, \mathrm{D}_{0} * \mathrm{RTiM}$ and $\mathrm{D}_{15} * \mathrm{RF}$ being significantly higher than the control. Ammonium-N was significantly $(\mathrm{P}=0.02)$ different between the interactions on the $30^{\text {th }}$ day during SR16 season. The highest mineralization of mineral $\mathrm{N}$ during SR16 season occurred on the $45^{\text {th }}$ day after planting under tillage, soil fertility resources and interactions in Meru South.

During LR17 season, $\mathrm{NO}_{3}{ }^{-}-\mathrm{N}$ was not significantly different between the tillage systems on all the sampling days in Meru South (Figure 3C) while $\mathrm{NH}_{4}{ }^{+}-\mathrm{N}$ was significantly different on the $60^{\text {th }}$ day after planting (Figure 3D). Ammonium-N was significantly higher under $\mathrm{D}_{15}$ by $46 \%$ compared with the $\mathrm{D}_{0}$ on the $60^{\text {th }}$ day (Figure 3D). At planting, 30 and $45^{\text {th }}$ days, mineral $\mathrm{N}$ content was higher under $\mathrm{D}_{0}$ compared with the $\mathrm{D}_{15}$ while on the $60^{\text {th }}$ and $90^{\text {th }}$ days it was higher under $\mathrm{D}_{15}$ (Figure $3 \mathrm{C}$ and $\mathrm{D}$ ). Under soil fertility

Table 5. Average soil chemical properties under soil fertility resources in Meru South and Kandara study sites at the end of study period.

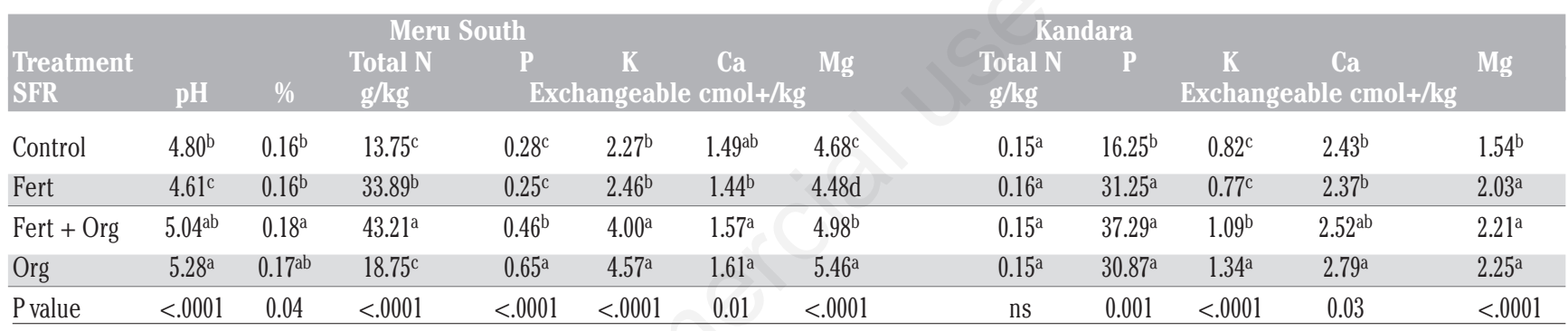

SFR, soil fertility resources; Control, no fertiliser; Fert, mineral fertiliser; Fert+Org, mineral fertiliser plus organic inputs; Org, organic inputs; ns, not significant-a-cSame superscript letters in the same column denote no significant difference between the treatment means at a given site at $\mathrm{P}=0.05$.

Table 6. Soil organic carbon (\%) concentration in different depths (cm) at Meru South and Kandara study sites.

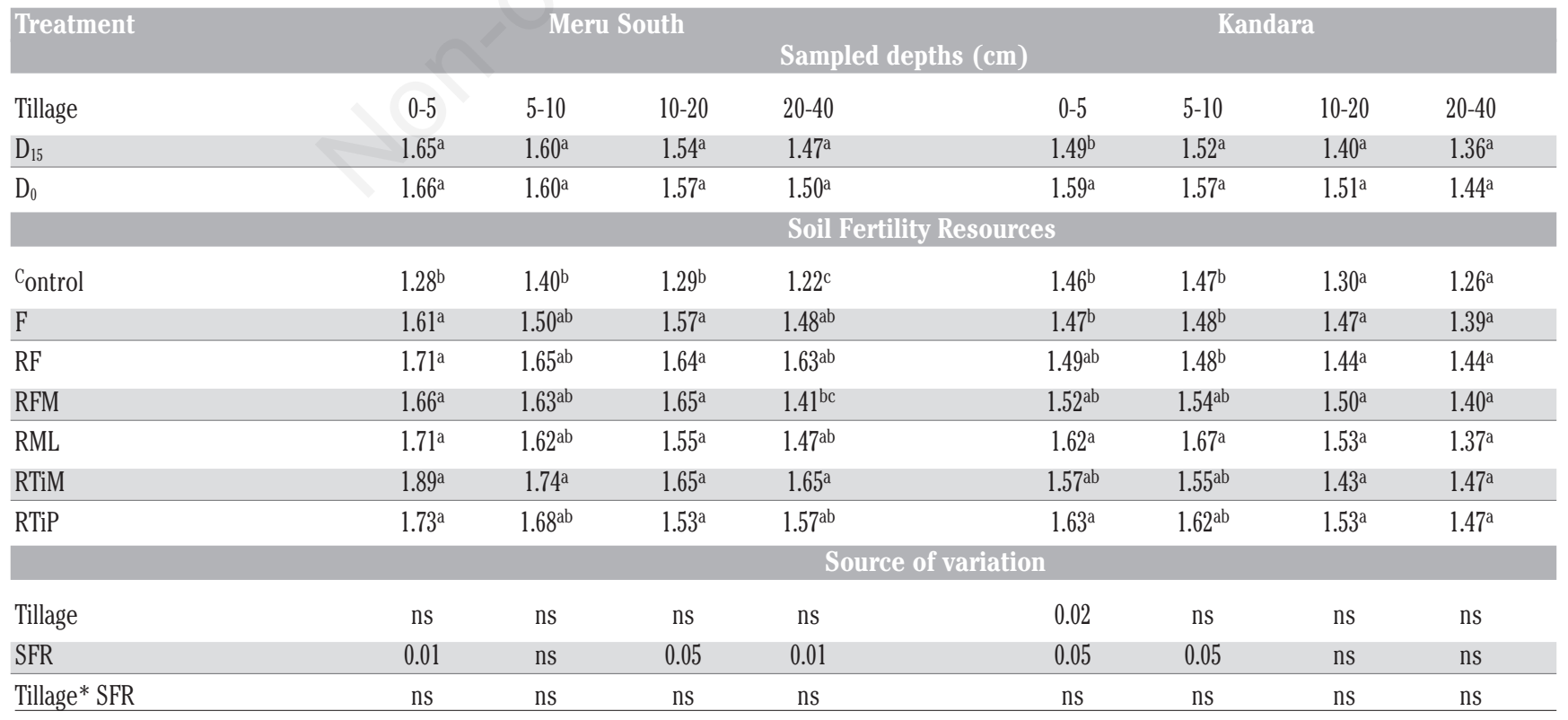

$\mathrm{D}_{15}$, conventional tillage; $\mathrm{D}_{0}$, minimum tillage; $\mathrm{F}$, mineral fertiliser; $\mathrm{RF}$, crop residue + mineral fertiliser; RFM, crop residue + mineral fertiliser + animal manure, $\mathrm{RML}$, crop residue + animal manure + legume intercrop, RTiM, crop residue + Tithonia diversifolia + animal manure, RTiP, crop residue + Tithonia diversifolia + phosphate rock; ns, not significant; SFR, soil fertility resources. a,b,cifferent letters indicate significant differences of the post hoc Tukey's HSD test performed in case effects of the model was significant $(\mathrm{P} \leq 0.05)$. 
resources, $\mathrm{NO}_{3}{ }^{-}-\mathrm{N}$ was significantly $(\mathrm{P}=0.03)$ different at planting under RML, F and RF by 69,68 and $60 \%$ compared with the control during LR17 season (Figure 4C). On the $30^{\text {th }}$ day, $\mathrm{NO}_{3}{ }^{-}-\mathrm{N}$ significantly $(\mathrm{P}<0.0001)$ increased under RF, RFM, RTiP, and RTiM by $231,205,91$ and $90 \%$ compared with the control. On the $60^{\text {th }}$ day, $\mathrm{NO}_{3}{ }^{-}-\mathrm{N}$ was significantly higher under RF and RTiM by 115 and $78 \%$, respectively compared with the control (Figure $4 \mathrm{C}$ ). $\mathrm{NH}_{4}{ }^{+}-\mathrm{N}$ was significantly different at planting, the $30^{\text {th }}$ and $45^{\text {th }}$ day after planting compared with the control (Figure 4D). At planting, $\mathrm{NH}_{4}{ }^{+}-\mathrm{N}$ was significantly different under $\mathrm{F}$ application by $104 \%$ compared with the control. On the $30^{\text {th }}$ day, $\mathrm{NH}_{4}{ }^{+}-\mathrm{N}$ was significantly higher under RFM and F by 155 and $131 \%$, respectively, compared with the control during LR17 season (Figure 4D). On the $45^{\text {th }}$ day, $\mathrm{NH}_{4}{ }^{+}-\mathrm{N}$ was significantly higher under $\mathrm{RML}$ and RFM compared with the control. In the LR17 season, $\mathrm{NO}_{3}{ }^{-}-\mathrm{N}$ was significantly $(\mathrm{P}=0.02)$ different under the interactions on the $60^{\text {th }}$ and $90^{\text {th }}$ day after planting while $\mathrm{NH}_{4}{ }^{+}-\mathrm{N}$ was significantly differ-

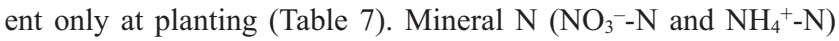
was highest on the $30^{\text {th }}$ day after planting under tillage, SFR and the interactions during LR17 season in Meru South.

In Kandara, Nitrate-N was significantly $(\mathrm{P}<0.0001)$ higher under $\mathrm{D}_{0}$ by $17 \%$ at planting and by $73 \%$ on the $30^{\text {th }}$ day compared with $\mathrm{D}_{15}$ during SR16 season (Figure 5A). Ammonium-N was significantly $(\mathrm{P}=0.01)$ higher under $\mathrm{D}_{0}$ by $30 \%$ at planting and $30^{\text {th }}$ day after planting compared with $\mathrm{D}_{15}$ (Figure $\left.5 \mathrm{~B}\right)$. Under soil fertility resources, soil $\mathrm{NO}_{3}{ }^{-}-\mathrm{N}$ was significantly $(\mathrm{P}<0.0001)$

Table 7. Mineral-N response under tillage* soil fertility resources interactions in the $\mathbf{0 - 2 0} \mathrm{cm}$ depth on different sampling dates during short rains 2016 season at Meru South site.

\begin{tabular}{|c|c|c|c|c|c|c|c|c|c|c|c|}
\hline \multirow[b]{3}{*}{ Tillage } & \multirow[b]{3}{*}{ SFR } & \multicolumn{10}{|c|}{ Sampling days after planting (SR16 season) } \\
\hline & & \multicolumn{5}{|c|}{ Nitrate-N $(\mathrm{ppm} / 100 \mathrm{~g})$} & \multicolumn{5}{|c|}{ Ammonium-N (ppm/100g) } \\
\hline & & 0 & 30 & 45 & 60 & 90 & 0 & 30 & 45 & 60 & 90 \\
\hline \multirow{7}{*}{$\begin{array}{l}\text { Conventional* } \\
\left(D_{15}\right)\end{array}$} & C & $9.50^{\mathrm{a}}$ & $16.87^{\mathrm{g}}$ & $40.42^{\mathrm{a}}$ & $14.54^{\mathrm{a}}$ & 7.39ef & $4.03^{a}$ & $14.36^{\mathrm{d}}$ & $22.39^{a}$ & $15.49^{a}$ & $13.22^{\mathrm{a}}$ \\
\hline & $\mathrm{F}$ & $16.65^{\mathrm{a}}$ & $19.42^{\mathrm{fg}}$ & $22.76^{\mathrm{a}}$ & $22.22^{\mathrm{a}}$ & $8.76^{\mathrm{de}}$ & $9.60^{\mathrm{a}}$ & $15.68^{\mathrm{cd}}$ & $25.10^{\mathrm{a}}$ & $29.39^{\mathrm{a}}$ & $4.89^{\mathrm{a}}$ \\
\hline & $\mathrm{RF}$ & $8.46^{\mathrm{a}}$ & $29.13^{\mathrm{cd}}$ & $45.64^{\mathrm{a}}$ & $9.90^{\mathrm{a}}$ & $10.21^{\mathrm{cd}}$ & $4.85^{\mathrm{a}}$ & $27.37^{\mathrm{a}}$ & $23.26^{\mathrm{a}}$ & $16.04^{\mathrm{a}}$ & $18.66^{\mathrm{a}}$ \\
\hline & RFM & $19.63^{\mathrm{a}}$ & $38.36^{\mathrm{b}}$ & $43.36^{\mathrm{a}}$ & $15.06^{\mathrm{a}}$ & $17.04^{\mathrm{a}}$ & $9.92^{\mathrm{a}}$ & $15.05^{\mathrm{d}}$ & $24.14^{\mathrm{a}}$ & $24.78^{a}$ & $12.17^{\mathrm{a}}$ \\
\hline & RML & $14.34^{\mathrm{a}}$ & $25.97^{\mathrm{d}}$ & $40.02^{\mathrm{a}}$ & $12.22^{\mathrm{a}}$ & $4.83^{g}$ & $14.98^{\mathrm{a}}$ & $8.85^{\mathrm{e}}$ & $24.60^{\mathrm{a}}$ & $22.84^{\mathrm{a}}$ & $22.33^{\mathrm{a}}$ \\
\hline & RTiM & $10.36^{\mathrm{a}}$ & $25.86^{\mathrm{de}}$ & $31.14^{\mathrm{a}}$ & $11.33^{\mathrm{a}}$ & $12.38^{\mathrm{b}}$ & $5.44^{\mathrm{a}}$ & $17.65^{\mathrm{cd}}$ & $26.35^{\mathrm{a}}$ & $27.02^{\mathrm{a}}$ & $26.83^{\mathrm{a}}$ \\
\hline & RTiP & $5.97^{\mathrm{a}}$ & $23.74^{\mathrm{e}}$ & $36.88^{\mathrm{a}}$ & $15.02^{\mathrm{a}}$ & $7.67^{\mathrm{ef}}$ & $5.52^{\mathrm{a}}$ & $20.39^{b c}$ & $24.72^{\mathrm{a}}$ & $17.83^{\mathrm{a}}$ & $24.60^{\mathrm{a}}$ \\
\hline \multirow{7}{*}{$\begin{array}{l}\text { Minimum* } \\
\left(D_{0}\right)\end{array}$} & $\mathrm{C}$ & $27.32^{\mathrm{a}}$ & $37.22^{b}$ & $26.31^{\mathrm{a}}$ & $2.83^{\mathrm{a}}$ & $9.78^{d}$ & $5.77^{\mathrm{a}}$ & $15.43^{\mathrm{d}}$ & $23.68^{a}$ & $2.49^{\mathrm{a}}$ & $6.84^{\mathrm{a}}$ \\
\hline & $\mathrm{F}$ & $24.40^{\mathrm{a}}$ & $56.01^{\mathrm{a}}$ & $18.91^{\mathrm{a}}$ & $16.10^{\mathrm{a}}$ & $9.81^{\mathrm{d}}$ & $8.03^{\mathrm{a}}$ & $19.97^{\mathrm{bc}}$ & $17.90^{\mathrm{a}}$ & $18.47^{\mathrm{a}}$ & $16.68^{\mathrm{a}}$ \\
\hline & $\mathrm{RF}$ & $13.58^{\mathrm{a}}$ & $22.22^{\mathrm{ef}}$ & $34.15^{\mathrm{a}}$ & $16.67^{\mathrm{a}}$ & $5.30^{\mathrm{g}}$ & $16.97^{\mathrm{a}}$ & $25.69^{\mathrm{ab}}$ & $26.49^{a}$ & $17.63^{\mathrm{a}}$ & $19.69^{\mathrm{a}}$ \\
\hline & RFM & $17.84^{\mathrm{a}}$ & $16.82^{\mathrm{g}}$ & $22.36^{\mathrm{a}}$ & $11.83^{\mathrm{a}}$ & $6.53^{\mathrm{fg}}$ & $15.90^{\mathrm{a}}$ & $13.28^{d}$ & $27.82^{\mathrm{a}}$ & $8.59^{\mathrm{a}}$ & $7.68^{\mathrm{a}}$ \\
\hline & RML & $29.63^{\mathrm{a}}$ & $7.89 \mathrm{~h}$ & $24.83^{\mathrm{a}}$ & $10.51^{\mathrm{a}}$ & $5.40^{\mathrm{g}}$ & $8.91^{\mathrm{a}}$ & $27.84^{\mathrm{a}}$ & $23.95^{\mathrm{a}}$ & $27.19^{\mathrm{a}}$ & $14.02^{\mathrm{a}}$ \\
\hline & RTiM & $15.97^{\mathrm{a}}$ & $31.36^{\mathrm{c}}$ & $29.18^{a}$ & $10.99^{a}$ & $11.81^{b c}$ & $5.63^{\mathrm{a}}$ & $14.60^{d}$ & $24.20^{\mathrm{a}}$ & $18.86^{\mathrm{a}}$ & $16.39^{\mathrm{a}}$ \\
\hline & RTiP & $19.51^{\mathrm{a}}$ & $31.02^{c}$ & $44.81^{\mathrm{a}}$ & $13.79^{\mathrm{a}}$ & $8.77^{\mathrm{de}}$ & $13.16^{\mathrm{a}}$ & $21.77^{\mathrm{b}}$ & $24.47^{\mathrm{a}}$ & $16.36^{\mathrm{a}}$ & $20.23^{\mathrm{a}}$ \\
\hline$P$ & & ns & $<.0001$ & ns & ns & 0.03 & ns & 0.02 & ns & ns & ns \\
\hline
\end{tabular}

SFR, soil fertility resources abbreviations; F, mineral fertiliser; RF, crop residue + mineral fertiliser; RFM, crop residue + mineral fertiliser + animal manure; RML, crop residue + animal manure +legume intercrop; RTiM, crop residue + Tithonia diversifolia + animal manure; RTiP, crop residue + Tithonia diversifolia + phosphate rock; ns, not significant. ${ }^{\text {a-g }}$ Different letters indicate significant differences in the post hoc Tukey's HSD test performed in case effects of the model was significant $(\mathrm{P} \leq 0.05)$.

Table 8. Mineral-N response under tillage* soil fertility resources interactions in the $\mathbf{0 - 2 0} \mathrm{cm}$ depth on different sampling dates during long rains 2017 season at Meru South site.

\begin{tabular}{|c|c|c|c|c|c|c|c|c|c|c|c|}
\hline \multirow[b]{3}{*}{ Tillage } & \multirow[b]{3}{*}{ SFR } & \multirow{2}{*}{\multicolumn{10}{|c|}{ Sampling days after planting (LR17 season) }} \\
\hline & & & & & & & & & & & \\
\hline & & 0 & 30 & 45 & 60 & 90 & 0 & 30 & 45 & 60 & 90 \\
\hline \multirow{7}{*}{$\begin{array}{l}\text { Conventional } \\
\left(D_{15}\right)\end{array}$} & $\mathrm{C}$ & $9.70^{\mathrm{ab}}$ & $16.88^{\mathrm{a}}$ & $3.85^{\mathrm{a}}$ & $3.96 \mathrm{~h}$ & $4.14^{\mathrm{h}}$ & $6.84^{\mathrm{de}}$ & $28.12^{\mathrm{ab}}$ & $1.82^{\mathrm{f}}$ & $5.13^{\mathrm{a}}$ & $3.37^{\mathrm{a}}$ \\
\hline & $\mathrm{F}$ & $23.25^{\mathrm{a}}$ & $23.34^{\mathrm{a}}$ & $8.65^{\mathrm{a}}$ & $7.93^{\text {bcdef }}$ & $6.49^{\text {bcdef }}$ & $22.13^{\mathrm{a}}$ & $40.60^{\mathrm{a}}$ & $15.56^{\mathrm{c}}$ & $5.31^{\mathrm{a}}$ & $3.45^{\mathrm{a}}$ \\
\hline & $\mathrm{RF}$ & $23.57^{\mathrm{a}}$ & $63.32^{\mathrm{a}}$ & $8.41^{\mathrm{a}}$ & $16.04^{\mathrm{a}}$ & $11.29^{\mathrm{a}}$ & $5.24^{\mathrm{ef}}$ & $23.10^{\mathrm{ab}}$ & $4.07^{\mathrm{ef}}$ & $6.19^{\mathrm{a}}$ & $3.73^{\mathrm{a}}$ \\
\hline & RFM & $17.67^{\mathrm{a}}$ & $51.69^{\mathrm{a}}$ & $8.97^{\mathrm{a}}$ & $7.83^{\text {cdef }}$ & $6.43^{\text {cdef }}$ & $4.65^{\mathrm{ef}}$ & $46.69^{a}$ & $29.43^{b}$ & $9.69^{\mathrm{a}}$ & $2.52^{\mathrm{a}}$ \\
\hline & RML & $15.05^{\mathrm{a}}$ & $35.57^{\mathrm{a}}$ & $8.31^{\mathrm{a}}$ & $6.97^{\text {efg }}$ & $5.92^{\mathrm{efg}}$ & $6.53^{\mathrm{def}}$ & $29.23^{\mathrm{ab}}$ & $10.86^{\mathrm{cd}}$ & $11.94^{\mathrm{a}}$ & $4.05^{\mathrm{a}}$ \\
\hline & RTiM & $18.00^{\mathrm{a}}$ & $41.48^{\mathrm{a}}$ & $5.72^{\mathrm{ab}}$ & $9.50^{\mathrm{b}}$ & $7.42^{\mathrm{b}}$ & $4.62^{\mathrm{ef}}$ & $14.43^{\mathrm{ab}}$ & $12.43^{c}$ & $15.34^{\mathrm{a}}$ & $5.22^{\mathrm{a}}$ \\
\hline & RTiP & $14.11^{\mathrm{a}}$ & $33.04^{\mathrm{a}}$ & $2.73^{\mathrm{ab}}$ & $8.74^{\text {bcd }}$ & $6.97^{\mathrm{bcd}}$ & $3.88^{\mathrm{f}}$ & $33.53^{\mathrm{a}}$ & $3.61^{\mathrm{ef}}$ & $12.37^{\mathrm{a}}$ & $3.92^{\mathrm{a}}$ \\
\hline \multirow{7}{*}{$\begin{array}{l}\text { Minimum } \\
\left(D_{0}\right)\end{array}$} & C & $16.37^{\mathrm{a}}$ & $17.58^{\mathrm{a}}$ & $1.90^{\mathrm{ab}}$ & $6.33^{\mathrm{fg}}$ & $5.54^{\mathrm{fg}}$ & $6.97 \mathrm{de}$ & $17.06^{\mathrm{ab}}$ & $3.06^{\mathrm{ef}}$ & $5.22^{\mathrm{a}}$ & $4.43^{\mathrm{a}}$ \\
\hline & $\mathrm{F}$ & $20.73^{\mathrm{a}}$ & $37.42^{\mathrm{a}}$ & $5.29^{\mathrm{a}}$ & $8.28^{\text {bcde }}$ & $6.70^{\text {bcde }}$ & $6.12^{\text {def }}$ & $51.61^{\mathrm{a}}$ & $5.32^{\mathrm{ef}}$ & $2.63^{\mathrm{a}}$ & $4.32^{\mathrm{a}}$ \\
\hline & $\mathrm{RF}$ & $18.09^{\mathrm{a}}$ & $65.33^{\mathrm{a}}$ & $10.68^{\mathrm{a}}$ & $6.15^{\mathrm{g}}$ & $5.43^{\mathrm{g}}$ & $8.68^{\mathrm{cd}}$ & $16.77^{\mathrm{ab}}$ & $6.72^{\mathrm{de}}$ & $5.15^{\mathrm{a}}$ & $3.66^{\mathrm{a}}$ \\
\hline & RFM & $13.60^{\mathrm{a}}$ & $57.17^{\mathrm{a}}$ & $12.03^{\mathrm{a}}$ & $8.52^{\text {bcde }}$ & $6.84^{\text {bcde }}$ & $8.36^{\mathrm{cd}}$ & $55.35^{\mathrm{a}}$ & $11.26^{\mathrm{cd}}$ & $5.70^{\mathrm{a}}$ & $4.40^{\mathrm{a}}$ \\
\hline & RML & $29.15^{\mathrm{a}}$ & $28.16^{a}$ & $10.15^{\mathrm{a}}$ & $7.47^{\text {cdefg }}$ & $6.21^{\text {cdefg }}$ & $10.06^{\mathrm{bc}}$ & $30.75^{\mathrm{a}}$ & $34.41^{\mathrm{a}}$ & $8.79^{a}$ & $4.93^{\mathrm{a}}$ \\
\hline & RTiM & $14.99^{\mathrm{a}}$ & $26.07^{\mathrm{a}}$ & $5.97^{\mathrm{ab}}$ & $8.82^{\mathrm{bc}}$ & $7.01^{\mathrm{bc}}$ & $6.48^{\text {def }}$ & $32.39^{\mathrm{a}}$ & $10.84^{\mathrm{cd}}$ & $0.97^{\mathrm{a}}$ & $4.90^{\mathrm{a}}$ \\
\hline & RTiP & $14.40^{\mathrm{a}}$ & $34.99^{\mathrm{a}}$ & $14.42^{\mathrm{a}}$ & 7.17 defg & $6.03^{\text {defg }}$ & $12.49^{b}$ & $24.16^{\mathrm{ab}}$ & $2.40^{\mathrm{ef}}$ & $6.79^{\mathrm{a}}$ & $2.78^{\mathrm{a}}$ \\
\hline \multicolumn{2}{|l|}{$P$} & ns & ns & ns & 0.02 & 0.02 & 0.006 & ns & 0.01 & ns & ns \\
\hline
\end{tabular}

F, mineral fertiliser; RF, crop residue + mineral fertiliser; RFM, crop residue + mineral fertiliser + animal manure; RML, crop residue + animal manure + legume intercrop; RTiM, crop residue + Tithonia diversifo-

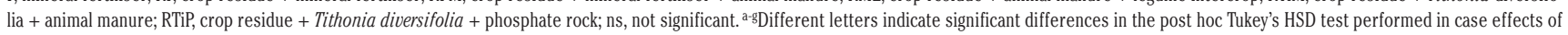
the model was significant $(\mathrm{P} \leq 0.05)$. 
A

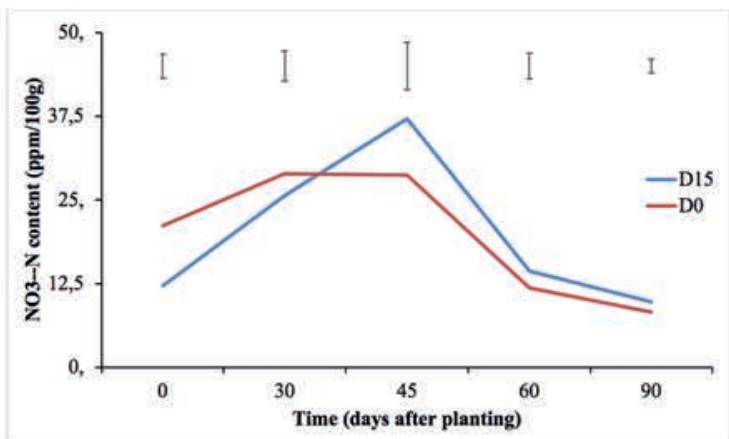

hsd $=0.05$

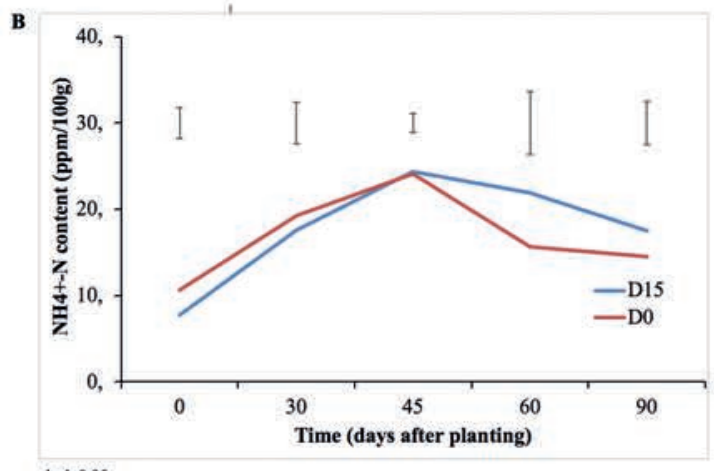

hod -0.05

c

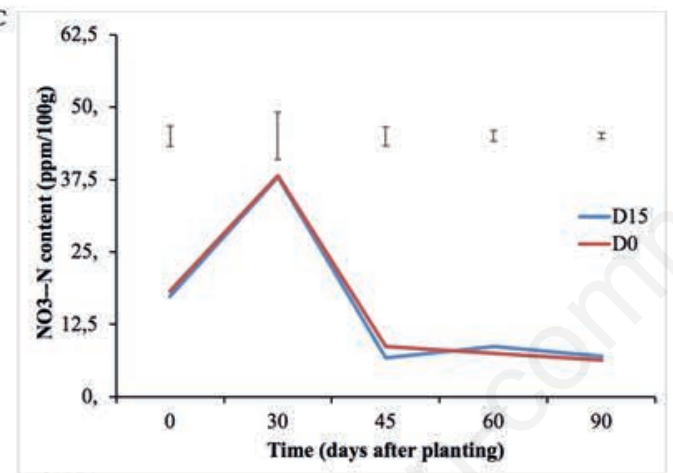

hsd-0.05

D

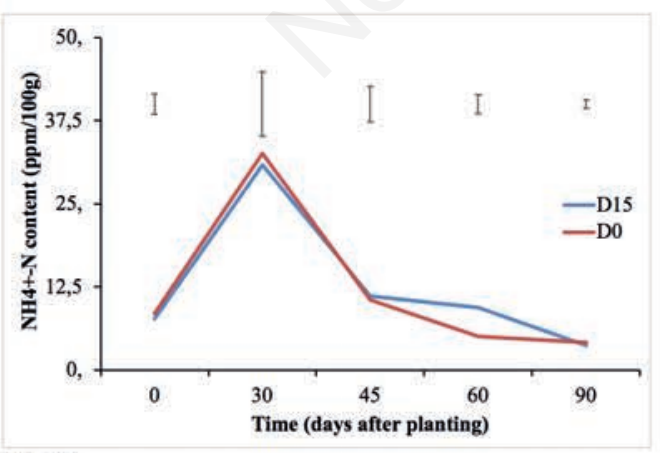

hsd $=0.05$

Figure 3. Mineral nitrogen response to different tillage systems in $0-20 \mathrm{~cm}$ depth during the short rain 2016 season: $\mathrm{A}) \mathrm{NO}_{3}^{-}-\mathrm{N}$ and B) $\mathrm{NH}_{4}{ }^{+}-\mathrm{N}$ and long rain 2017; C) $\mathrm{NO}_{3}{ }^{-}-\mathrm{N}$ and $\left.\mathrm{D}\right) \mathrm{NH}_{4}{ }^{+}-\mathrm{N}$ season at Meru South site; $D_{15}$, conventional tillage; $D_{0}$, minimum tillage. Significant differences of the post hoc Tukey's HSD test performed in case effects of the model was significant at $\mathrm{P} \leq 0.05$.

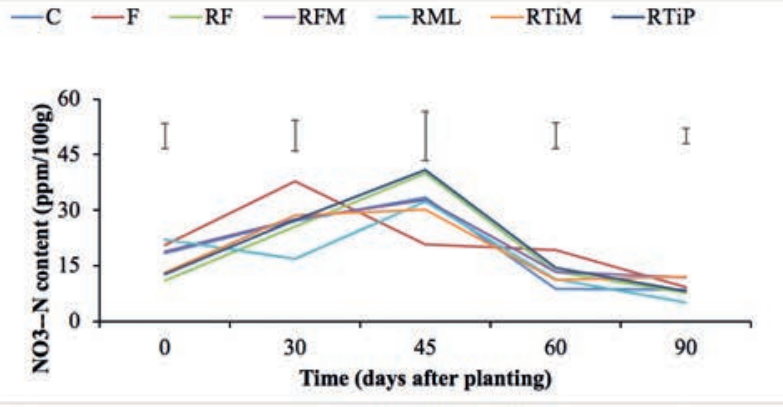

A $\quad$ hsd $=0.05$

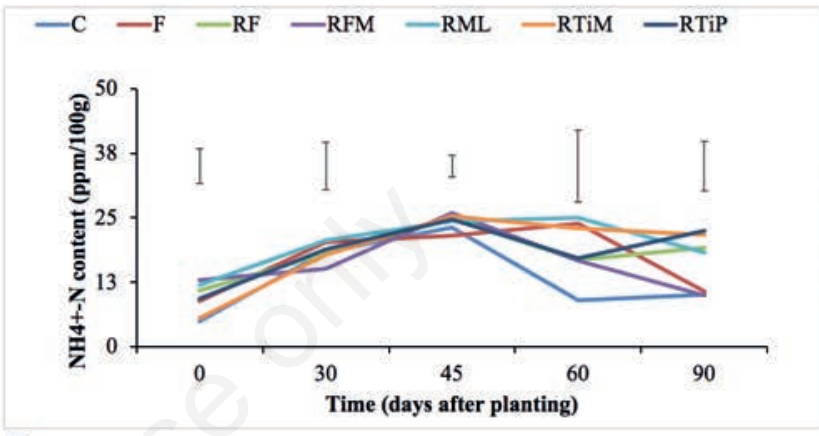

B hasd -0.05

$-\mathrm{C}-\mathrm{F}-\mathrm{RF}-\mathrm{RFM}-\mathrm{RML}-\mathrm{RTiM}-\mathrm{RTiP}$

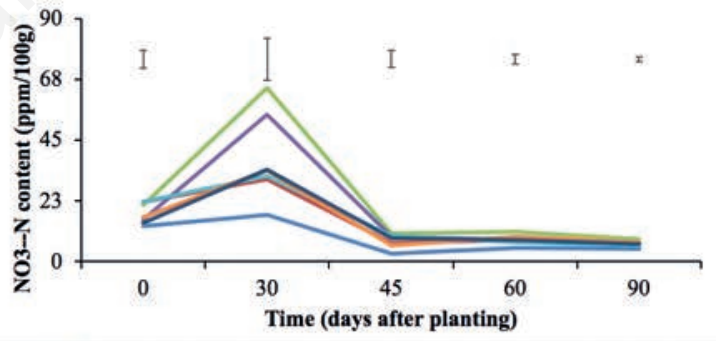

C hsd-0.05
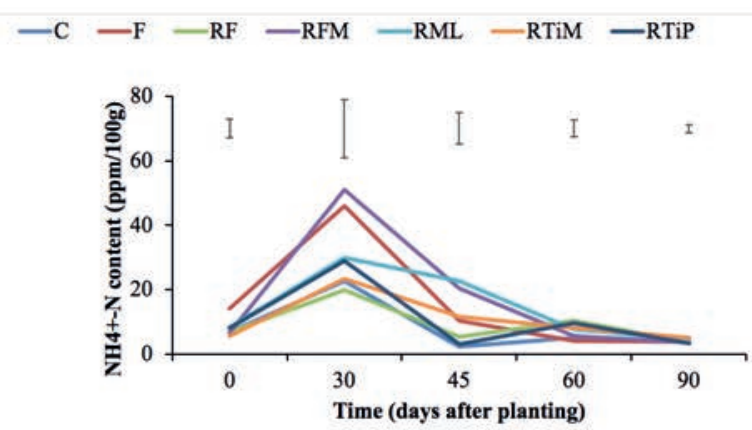

D hsd $=0.05$

Figure 4. Mineral nitrogen response to various soil fertility resources during the short rain 2016 season: $\mathrm{A}) \mathrm{NO}_{3}{ }^{-}-\mathrm{N}$ and $\mathrm{B}$ ) $\mathrm{NH}_{4}{ }^{+}-\mathrm{N}$ and long rain 2017; C) $\mathrm{NO}_{3}{ }^{-}-\mathrm{N}$ and $\left.\mathrm{D}\right) \mathrm{NH}_{4}{ }^{+}-\mathrm{N}$ season in Meru South site. F, mineral fertiliser, RF, crop residue + mineral fertiliser, RFM, crop residue + mineral fertiliser + animal manure; RML, crop residue + animal manure +legume intercrop; RTiM, crop residue + Tithonia diversifolia + animal manure, RTiP, crop residue + Tithonia diversifolia + phosphate rock. Significant differences of the post hoc Tukey's HSD test performed in case effects of the model was significant at $P \leq 0.05$. 
different on all the sampled days during SR16 season (Figure $6 \mathrm{~A}$ ). At planting $\mathrm{NO}_{3}{ }^{-}-\mathrm{N}$ was significantly different under $\mathrm{F}, \mathrm{RF}$, RFM, and RML by $37,26,22$ and $13 \%$ compared with the control during SR16 season (Figure 6A). On the $30^{\text {th }}$ day, $\mathrm{NO}_{3}{ }^{-}-\mathrm{N}$ was significantly higher under F, RF, RFM, and RML by 189 , 136, 113 and $69 \%$ compared with the control. Application of RTiM and RF significantly increased $\mathrm{NO}_{3}{ }^{-} \mathrm{N}$ by 205 and $151 \%$, respectively, compared with the control on the $45^{\text {th }}$ day during SR16 season in Kandara. Ammonium-N was significantly different under SFR on all the sampling days except on the $90^{\text {th }}$ day during SR16 season in Kandara (Figure 6B). $\mathrm{NH}_{4}{ }^{+}-\mathrm{N}$ was significantly higher under RTiM and RFM at planting by 91 and $55 \%$ and on the $30^{\text {th }}$ day by 73 and $19 \%$, respectively, compared with the control. On the $45^{\text {th }}$ day, $\mathrm{NH}_{4}{ }^{+}-\mathrm{N}$ was significantly higher under $\mathrm{F}$ by $119 \%$ and under RTiM by $50 \%$ on the $60^{\text {th }}$ day compared with the control during SR17 season (Figure 6B). Under the interactions, $\mathrm{NO}_{3}{ }^{-}-\mathrm{N}$ was significantly different throughout the LR17 season on all the sampling dates (Table 9). At planting and on the $30^{\text {th }}$ day after planting $\mathrm{NO}_{3}{ }^{-}-\mathrm{N}$ was significantly highest under $\mathrm{D}_{0} * \mathrm{~F}$ interaction by 61 and $361 \%$, respectively, compared with $\mathrm{D}_{15} *$ Control interaction (Table 9). On the $45^{\text {th }}$ day, $\mathrm{NO}_{3}{ }^{-}-\mathrm{N}$ was significantly highest under $\mathrm{D}_{0} * \mathrm{RTiM}$ interaction by $213 \%$ compared with the $\mathrm{D}_{15} *$ Control interaction. Nitrate-N was significantly highest under $\mathrm{D}_{0} * \mathrm{RFM}$ and $\mathrm{D}_{15} * \mathrm{RF}$ on the $60^{\text {th }}$ day and under $\mathrm{D}_{15} * \mathrm{RF}$ on the $90^{\text {th }}$ day compared with the control during SR16 season. Ammonium-N was highest under D0*RTiM interaction on the $30^{\text {th }}$ day and under $\mathrm{D}_{15} * \mathrm{RF}$ on the $90^{\text {th }}$ day compared with the control. Nitrate- $\mathrm{N}$ was highest on the $45^{\text {th }}$ day while $\mathrm{NH}_{4}{ }^{+}-\mathrm{N}$ was highest on the $30^{\text {th }}$ day under tillage, SFR and under the interactions during SR16 season in Kandara site. During LR17 season, $\mathrm{NO}_{3}{ }^{-}-\mathrm{N}$ was significantly higher under $\mathrm{D}_{15}$ on the $30^{\text {th }}(\mathrm{P}=0.004)$ and $60^{\text {th }}(\mathrm{P}=0.02)$ day after planting compared with the $\mathrm{D}_{0}$ in Kandara (Figure $5 \mathrm{C}$ ). Ammonium-N content was significantly $(\mathrm{P}=0.01)$ different between the tillage systems only at planting during LR17 season (Figure 5D). Under soil fertility resources, $\mathrm{NO}_{3}{ }^{-}-\mathrm{N}$ was significantly higher under $\mathrm{F}, \mathrm{RFM}$, RF, RTiM, RML and RTiP 163, 159, 84, 70, 67 and 60\% compared with the control on the $30^{\text {th }}$ day during LR17 season (Figure 6C). On the $45^{\text {th }}$ day, $\mathrm{NO}_{3}{ }^{-} \mathrm{N}$ was significantly higher under RFM and F by 296 and $260 \%$, respectively, compared with the control. While on the $60^{\text {th }}$ day, $\mathrm{NO}_{3}{ }^{-}-\mathrm{N}$ was significantly higher under RFM and RML by 131 and 70\%, respectively, compared with the control (Figure 6C). Compared with the control, $\mathrm{NH}_{4}{ }^{+}-\mathrm{N}$ was significantly different among SFR at planting and on the $45^{\text {th }}$ day during LR17 season at Kandara site (Figure 6D). On the $45^{\text {th }}$ day, $\mathrm{NH}_{4}{ }^{+}-\mathrm{N}$ was significantly higher under RTiP by $174 \%$ compared with the control. Under the interactions, $\mathrm{NO}_{3}^{-}-\mathrm{N}$ was significantly $(\mathrm{P}=0.006)$ different only on the $30^{\text {th }}$ day during LR17 season (Table 10). Ammonium-N was significantly different at planting, on the $30^{\text {th }}$ and $60^{\text {th }}$ day in Kandara site during LR17 season (Table 10). Both $\mathrm{NO}_{3}{ }^{-}-\mathrm{N}$ and $\mathrm{NH}_{4}{ }^{+}-\mathrm{N}$ was highest on the $30^{\text {th }}$ day under tillage, SFR and the interactions during LR17 season in Kandara site.
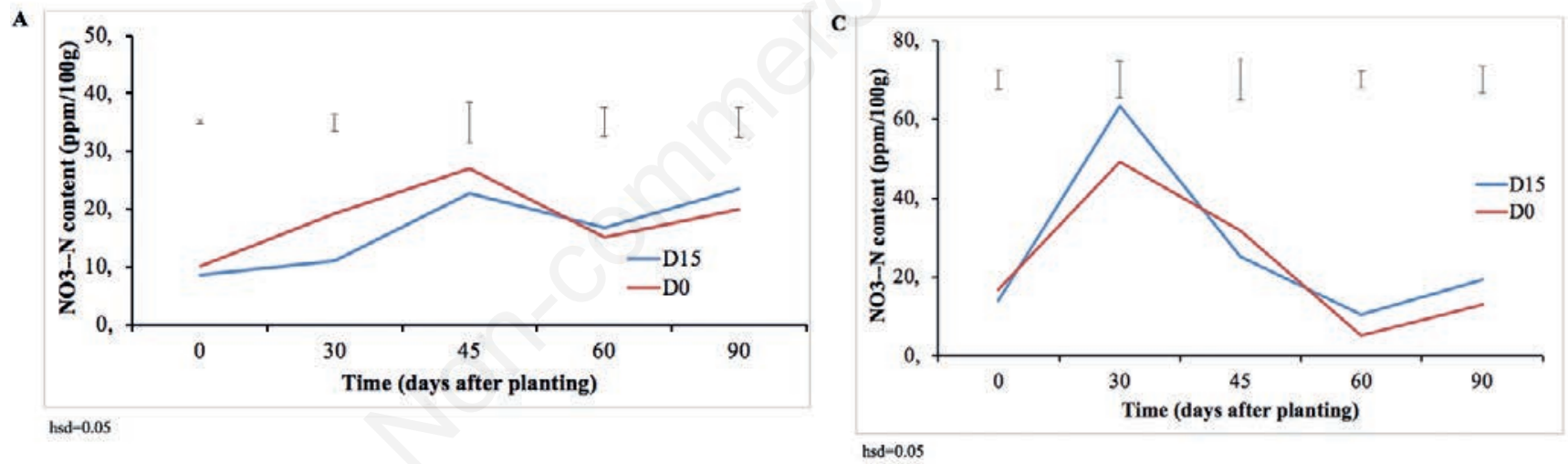

B

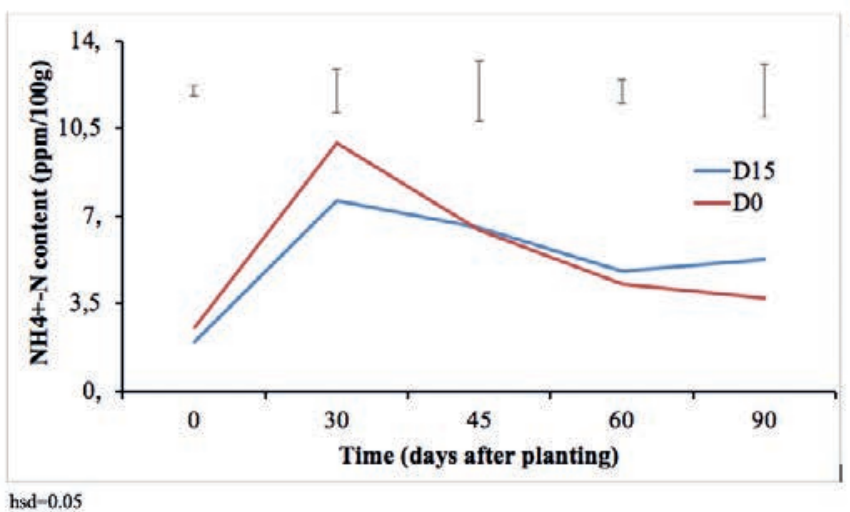

D

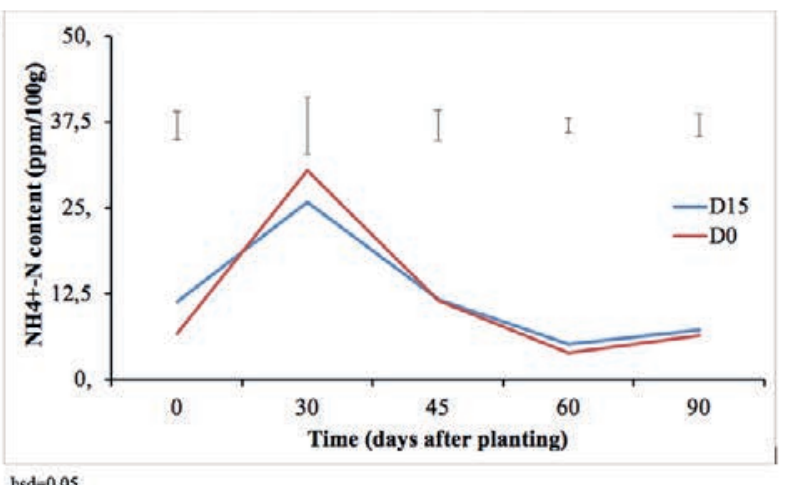

hsd -0.05

Figure 5. Mineral nitrogen response to different tillage systems in 0-20 cm depth during the short rain 2016 season: $\mathrm{A}) \mathrm{NO}_{3}{ }^{-}-\mathrm{N}$ and $\mathrm{B}$ ) $\mathrm{NH}_{4}{ }^{+}-\mathrm{N}$ and long rain 2017; C) $\mathrm{NO}_{3}{ }^{-}-\mathrm{N}$ and $\left.\mathrm{D}\right) \mathrm{NH}_{4}{ }^{+}-\mathrm{N}$ season in Kandara site; $\mathrm{D}_{15}=$ Conventional tillage; $\mathrm{D}_{0}=$ Minimum tillage; Significant differences of the post hoc Tukey's HSD test performed in case effects of the model was significant at $P \leq 0.05$. 


\section{Discussion}

Soil bulk density is a frequently measured soil quality parameter in tillage experiments (Logsdon and Karlen, 2004). In our study, tillage significantly influenced bulk density in Kandara site
(Table 2). Ferreras et al. (2000) also reported greater soil bulk density under conservation tillage than conventional tillage. Bulk density was not significantly different between the minimum and conventional tillage systems at Meru South site. This corroborates with the findings of several authors like Antichi et al. (2011); Lou

Table 9. Mineral-N response under tillage* soil fertility resources interactions in the $\mathbf{0 - 2 0} \mathrm{cm}$ depth on different sampling dates during short rains 2016 season at Kandara site.

\begin{tabular}{|c|c|c|c|c|c|c|c|c|c|c|c|}
\hline \multirow[b]{3}{*}{ Tillage } & \multirow[b]{3}{*}{ SFR } & \multicolumn{10}{|c|}{ Sampling days after planting (SR16 season) } \\
\hline & & \multicolumn{5}{|c|}{ Nitrate-N (ppm/100g) } & \multicolumn{5}{|c|}{ Ammonium-N (ppm/100g) } \\
\hline & & 0 & 30 & 45 & 60 & 90 & 0 & 30 & 45 & 60 & 90 \\
\hline \multirow{7}{*}{$\begin{array}{l}\text { Conventional* } \\
\left(D_{15}\right)\end{array}$} & Control & $7.83^{\mathrm{hi}}$ & $7.15^{j}$ & $17.93^{\mathrm{gh}}$ & $5.96 \mathrm{e}$ & $7.50^{\mathrm{h}}$ & $0.79^{f}$ & $6.94 \mathrm{fg}$ & $7.27 \mathrm{~cd}$ & $4.48^{\mathrm{a}}$ & $3.34^{\mathrm{a}}$ \\
\hline & $\mathrm{F}$ & $9.52^{\mathrm{e}}$ & $16.32^{\mathrm{e}}$ & $41.38^{b}$ & $20.98^{c}$ & $36.54^{\mathrm{b}}$ & $1.70^{\mathrm{e}}$ & $4.89^{\mathrm{h}}$ & $16.88^{\mathrm{a}}$ & $5.11^{\mathrm{a}}$ & $2.49^{\mathrm{a}}$ \\
\hline & $\mathrm{RF}$ & $9.37^{\mathrm{e}}$ & $16.03^{\mathrm{e}}$ & $32.08^{d}$ & $36.38^{\mathrm{a}}$ & $42.65^{\mathrm{a}}$ & $2.62^{\mathrm{bcd}}$ & $5.43^{\text {gh }}$ & $3.68^{\mathrm{gh}}$ & $5.03^{\mathrm{a}}$ & $4.85^{\mathrm{a}}$ \\
\hline & RFM & $7.90^{\mathrm{hi}}$ & $15.5 \mathrm{I}^{\mathrm{e}}$ & $24.16^{\mathrm{fg}}$ & $16.59^{\mathrm{cd}}$ & $12.27^{\mathrm{fg}}$ & $1.80^{\mathrm{e}}$ & $8.83^{e}$ & $3.06^{\mathrm{gh}}$ & $4.25^{\mathrm{a}}$ & $4.58^{\mathrm{a}}$ \\
\hline & RML & $9.46 \mathrm{e}$ & $7.54^{\mathrm{ij}}$ & $11.24^{\mathrm{ij}}$ & $5.28 \mathrm{e}$ & $12.75^{\mathrm{fg}}$ & $2.43^{\mathrm{bcd}}$ & $9.91^{\mathrm{de}}$ & $3.99^{g h}$ & $4.62^{\mathrm{a}}$ & $8.72^{\mathrm{a}}$ \\
\hline & RT'M & $8.53^{\mathrm{fg}}$ & $10.99^{\mathrm{gh}}$ & $23.82^{\mathrm{fg}}$ & $24.52^{\mathrm{bc}}$ & $43.56^{\mathrm{a}}$ & $2.00^{\mathrm{e}}$ & $8.82^{\mathrm{e}}$ & 6.29 def & $5.05^{\mathrm{a}}$ & $5.29^{\mathrm{a}}$ \\
\hline & RTiP & $7.22^{\mathrm{j}}$ & $3.86 \mathrm{k}$ & $7.86^{\mathrm{j}}$ & $7.33^{\mathrm{e}}$ & $8.89^{g h}$ & $2.35^{\text {bcde }}$ & $8.44^{\mathrm{ef}}$ & $4.44^{\mathrm{fgh}}$ & $4.91^{\mathrm{a}}$ & $7.56^{\mathrm{a}}$ \\
\hline \multirow{7}{*}{$\begin{array}{l}\text { Minimum* } \\
\left(D_{0}\right)\end{array}$} & Control & $8.33^{\text {gh }}$ & $9.89^{h i}$ & $22.62^{\mathrm{fg}}$ & $7.57^{\mathrm{e}}$ & $17.44^{\mathrm{e}}$ & $2.54^{\mathrm{bcd}}$ & $9.48^{\text {de }}$ & $4.80^{\mathrm{efg}}$ & $2.63^{\mathrm{a}}$ & $1.93^{\mathrm{a}}$ \\
\hline & F & $12.60^{\mathrm{a}}$ & $33.05^{\mathrm{a}}$ & $20.62^{\text {fgh }}$ & $28.11^{b}$ & $20.39 \mathrm{de}$ & $2.99^{b}$ & $11.89 \mathrm{bc}$ & $9.66^{\mathrm{b}}$ & $5.32^{\mathrm{a}}$ & $3.32^{\mathrm{a}}$ \\
\hline & $\mathrm{RF}$ & $11.08^{c}$ & $12.71^{\mathrm{fg}}$ & $34.03^{c}$ & $8.35^{\mathrm{e}}$ & $41.07^{\mathrm{ab}}$ & $1.60^{\mathrm{e}}$ & $6.38^{\text {gh }}$ & $10.77^{b}$ & $3.53^{\mathrm{a}}$ & $7.69^{\mathrm{a}}$ \\
\hline & RFM & $11.82^{\mathrm{b}}$ & $24.83^{c}$ & $14.98^{\mathrm{hi}}$ & $38.67^{\mathrm{a}}$ & $24.71^{\mathrm{cd}}$ & $1.97 \mathrm{e}$ & $10.64^{\mathrm{cd}}$ & $4.13^{\mathrm{gh}}$ & $4.28^{a}$ & $3.28^{\mathrm{a}}$ \\
\hline & RML & $8.85^{\mathrm{f}}$ & $28.83^{b}$ & $15.00^{\mathrm{hi}}$ & $8.81^{\mathrm{e}}$ & $11.93^{\text {fgh }}$ & $2.76^{\mathrm{bc}}$ & $6.66^{\mathrm{g}}$ & $6.64^{\text {de }}$ & $4.89^{\mathrm{a}}$ & $2.22^{\mathrm{a}}$ \\
\hline & $\mathrm{RT}^{\mathrm{i} M}$ & $8.13^{\text {gh }}$ & $8.77^{\text {hij }}$ & $56.22^{\mathrm{a}}$ & $6.80^{\mathrm{e}}$ & $15.09^{\mathrm{ef}}$ & $4.40^{\mathrm{a}}$ & $19.55^{\mathrm{a}}$ & $2.59^{\mathrm{h}}$ & $5.61^{\mathrm{a}}$ & $4.46^{\mathrm{a}}$ \\
\hline & RTiP & $9.55^{\mathrm{de}}$ & $16.53^{\mathrm{de}}$ & $25.23^{\text {ef }}$ & $7.05^{\mathrm{e}}$ & $9.28^{\text {gh }}$ & $1.69^{\mathrm{e}}$ & $4.85^{\mathrm{h}}$ & $6.63^{\mathrm{de}}$ & $3.59^{\mathrm{a}}$ & $3.26^{\mathrm{a}}$ \\
\hline$P$ & & 0.0004 & 0.0004 & 0.008 & 0.0003 & 0.003 & 0.0007 & 0.001 & 0.05 & ns & $\mathrm{ns}$ \\
\hline
\end{tabular}

SFR, soil fertility resources; F, mineral fertiliser; RF, crop residue + mineral fertiliser; RFM, crop residue + mineral fertiliser + animal manure; RML, crop residue + animal manure + legume intercrop, RTiM, crop

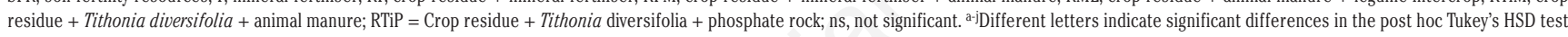
performed in case effects of the model was significant $(\mathrm{P} \leq 0.05)$.

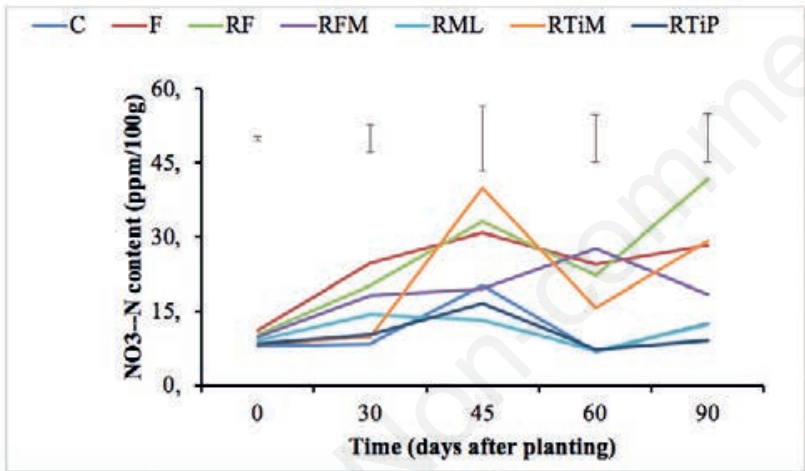

A hsd $=0.05$

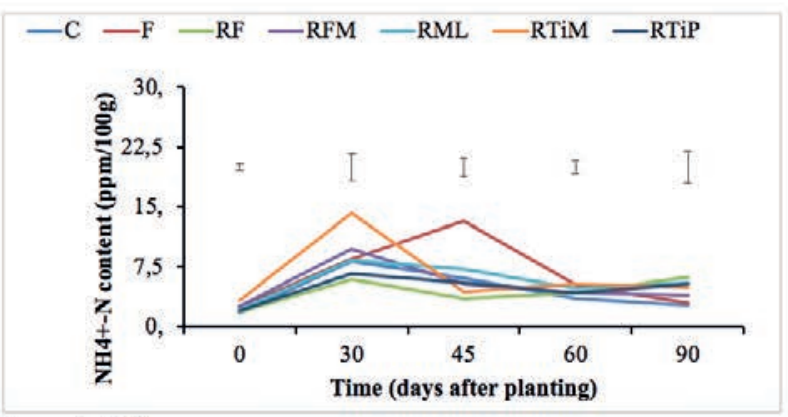

B hsd $=0.05$

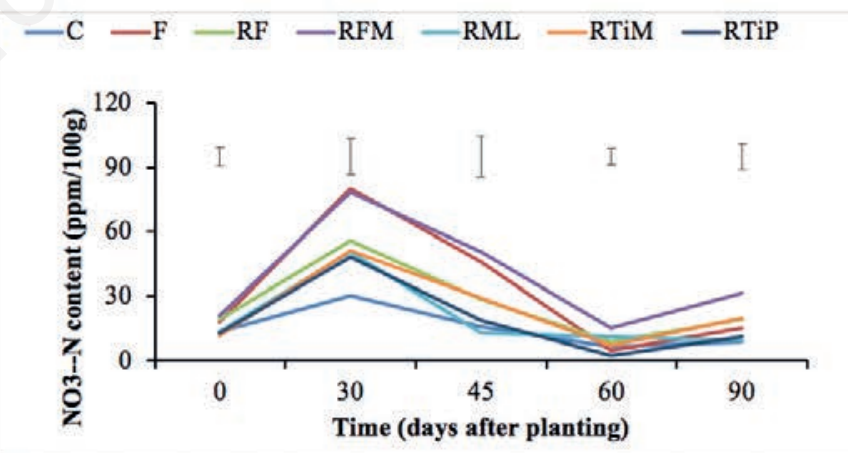

C hsd $=0.05$

$-\mathrm{C}-\mathrm{F}-\mathrm{RF}-\mathrm{RFM}-\mathrm{RML}-\mathrm{RTiM}-\mathrm{RTiP}$

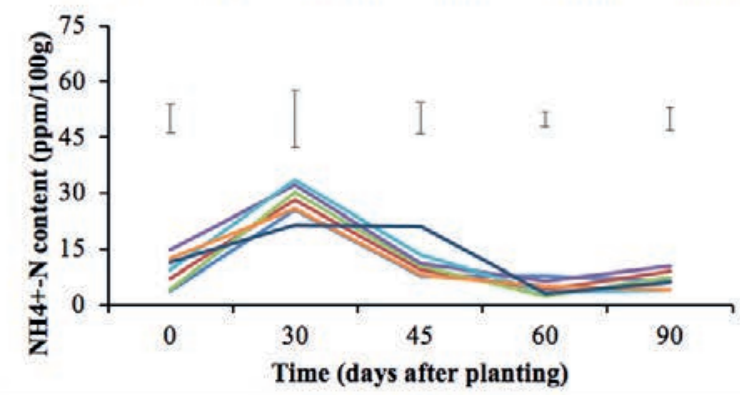

D hsd -0.05

Figure 6. Mineral nitrogen response to various soil fertility resources during the short rain 2016 season: $\mathrm{A}) \mathrm{NO}_{3}{ }^{-}-\mathrm{N}$ and $\mathrm{B}$ ) $\mathrm{NH}_{4}{ }^{+}-\mathrm{N}$ and long rain 2017; C) $\mathrm{NO}_{3}^{-}-\mathrm{N}$ and D) $\mathrm{NH}_{4}{ }^{+}-\mathrm{N}$ season in Meru South site. F, mineral fertiliser; RF, crop residue + mineral fertiliser; RFM, crop residue + mineral fertiliser + animal manure; RML, crop residue + animal manure + legume intercrop; RTiM, crop residue + Tithonia diversifolia + animal manure; RTiP, crop residue + Tithonia diversifolia + phosphate rock. Significant differences of the post hoc Tukey's HSD test performed in case effects of the model was significant at $P \leq 0.05$. 
et al. (2012); Askari and Holden (2015). Implementing no-tillage and stubble mulch tillage, Baumhardt, and Jones (2002) found no significant difference in soil bulk density. Application of SFRs' had no significant influence on bulk density at both sites. Wyngaard et al. (2012) also found that fertilization had no significant effect on bulk density. After conducting trials for two years, Motavalli et al. (2003) also observed that application of organic amendment, turkey litter had no significant effect on soil bulk density. Peck et al. (2011) found no difference in bulk density under integrated and organic treatments. Furthermore, Willekens et al. (2014) found that neither tillage nor compost influenced bulk density.

A significant increase in aggregate stability under minimum tillage compared to conventional tillage has been reported in some studies, for instance, Gicheru et al. (2004) and Paul et al. (2013). Conversely, this was not the case in our study, and the noneresponse might be attributable to soils with high clay content in both sites. Interaction of clay with other soil properties such as SOC content and differences in the mineralogical structure of the different clay types and ionic composition could be responsible for the varying results (Saygin et al., 2015). Ghuman and Sur (2001) also found no significant differences in aggregation indices between the minimum and conventional tillage treatments. Increased aggregate MWD under RML in Meru South (Table 2) was attributed to increased SOC (Table 6) at $0-5 \mathrm{~cm}$ depth. Increased SOC content increases soil aggregation (Meena et al., 2015), while SOM maintains soil aggregation (Mulumba and Lal, 2008). Some authors have reported that increased biomass input in legume crops-based cropping systems increases SOM content (Vieira et al., 2007; Wood et al., 2015).

Soil aggregation controls hydrological properties such as water holding capacity and storage of SOC (Bronick and Lal, 2005). In our study, hydraulic conductivity increased under application of crop residue, animal manure and legume intercrop (RML). Improvement of soil physical structure with the application of organic resources more so increased hydraulic conductivity has been reported (Macci et al., 2012). We attributed the insignificant effects on soil physical properties of the other SFRs used in this study to the short duration the experiments were conducted. Mosaddeghi et al. (2000) observed that application of animal manure or other organic resources has effects on soil physical properties when applied in high rates or over several years.

Changes in soil chemical properties after the study period were variable under application of soil fertility resources perhaps due to differences in the inputs' quality. This was consistent with the findings of Mucheru-Muna et al. (2014) in a study conducted in Central Kenya. The $\mathrm{pH}$ increased under application of RTiM and RML in both sites and under RFM and RTiP in Kandara site. This could be due to the organic acids and ligands that are produced during decomposition of organics enhancing the increase in soil $\mathrm{pH}$ (Hue, 1992). The increase in $\mathrm{pH}$ under SFR with organic resources could also be as a result of increased base-forming cations ( $\mathrm{Ca}$ and $\mathrm{K}$ in both sites and also $\mathrm{Mg}$ in Kandara) contained in organic resources thus decreasing soil acidity (Brady, 1990; Melero et al., 2007). Increase in soil $\mathrm{pH}$ as a result of using organic resources has been observed by several authors (Agbede, 2010; Mijangos and Garbisu, 2010).

On average, total $\mathrm{N}$ increased under the combination of mineral fertilizer and organic inputs. This could be due to complete uptake of the readily available $\mathrm{N}$ from the mineral fertilizer by the crop and partial uptake of $\mathrm{N}$ from the organic inputs. Phosphorous increased under soil fertility resources with mineral fertilizers; F, RF, RFM, and RTiP in both sites which was attributed to the readily available $P$ in the mineral fertilizers' and the fact that it is also an immobile element with high residual effect. This finding was consistent with the results of Onwonga et al. (2015). Potassium increased in soils that received sole organic resources (RTiM, RML) and with the combination of mineral fertilizer (RFM, RTiP). The increase in potassium could be explained by the fact that animal manure and Tithonia diversifolia contain high and readily decomposable potassium (Jama et al., 2000). Generally, soil fertility resources with animal manure showed an increase in soil nutrients. Application of animal manure tends to surpass the crop nutrient requirements leading to nutrient accumulation in agricultural

Table 10. Mineral-N response under tillage* soil fertility resources interactions in the $0-20 \mathrm{~cm}$ depth on different sampling dates during long rains 2017 season at Kandara site.

\begin{tabular}{|c|c|c|c|c|c|c|c|c|c|c|c|}
\hline \multirow[b]{2}{*}{ Tillage } & \multirow[b]{2}{*}{ SFR } & \multicolumn{10}{|c|}{ Sampling days after planting (SR17 season) } \\
\hline & & 0 & 30 & 45 & 60 & 90 & 0 & 30 & 45 & 60 & 90 \\
\hline \multirow{7}{*}{$\begin{array}{l}\text { Conventional * } \\
\left(D_{15}\right)\end{array}$} & $\mathrm{C}$ & $10.35^{\mathrm{a}}$ & $28.70^{\mathrm{f}}$ & $16.66^{\mathrm{a}}$ & $9.15^{\mathrm{a}}$ & $10.59^{\mathrm{a}}$ & $4.22^{\mathrm{d}}$ & $17.26^{\mathrm{de}}$ & $8.19^{\mathrm{a}}$ & $13.04^{\mathrm{a}}$ & $10.63^{\mathrm{a}}$ \\
\hline & $\mathrm{F}$ & $13.18^{\mathrm{a}}$ & $78.84^{\mathrm{b}}$ & $43.58^{\mathrm{a}}$ & $4.21^{\mathrm{a}}$ & $18.76^{\mathrm{a}}$ & $2.98^{\mathrm{d}}$ & $21.05^{\mathrm{d}}$ & $9.26^{\mathrm{a}}$ & $2.37^{\mathrm{de}}$ & $6.84^{\mathrm{a}}$ \\
\hline & $\mathrm{RF}$ & $17.98^{\mathrm{a}}$ & $59.03^{\mathrm{cd}}$ & $19.34^{\mathrm{a}}$ & $19.93^{\mathrm{a}}$ & $28.07^{\mathrm{a}}$ & $5.30^{\mathrm{d}}$ & $30.03^{\mathrm{c}}$ & $11.08^{\mathrm{a}}$ & $6.87^{\mathrm{b}}$ & $10.09^{\mathrm{a}}$ \\
\hline & RFM & $24.23^{\mathrm{a}}$ & $95.84^{\mathrm{a}}$ & $32.29^{a}$ & $19.22^{\mathrm{a}}$ & $27.43^{\mathrm{a}}$ & $15.74^{\mathrm{ab}}$ & $16.25^{\mathrm{de}}$ & $16.30^{\mathrm{a}}$ & $3.82^{\mathrm{d}}$ & $8.23^{\mathrm{a}}$ \\
\hline & RML & $14.42^{\mathrm{a}}$ & $42.17^{\mathrm{e}}$ & $14.26^{\mathrm{a}}$ & $11.96^{\mathrm{a}}$ & $5.06^{\mathrm{a}}$ & $16.15^{\mathrm{a}}$ & $46.79^{a}$ & $6.57^{\mathrm{a}}$ & $2.36^{\mathrm{de}}$ & $4.43^{\mathrm{a}}$ \\
\hline & RTiM & $9.44^{\mathrm{a}}$ & $74.47^{\mathrm{b}}$ & $23.69^{\mathrm{a}}$ & $6.52^{\mathrm{a}}$ & $31.30^{\mathrm{a}}$ & $15.43^{b}$ & $12.43^{\mathrm{eg}}$ & $10.52^{\mathrm{a}}$ & $3.84^{\mathrm{cd}}$ & $4.50^{\mathrm{a}}$ \\
\hline & RTiP & $8.69^{\mathrm{a}}$ & $63.45^{c}$ & $26.36^{\mathrm{a}}$ & $2.05^{\mathrm{a}}$ & $14.25^{\mathrm{a}}$ & $19.52^{\mathrm{a}}$ & $36.72^{\mathrm{bc}}$ & $19.79^{\mathrm{a}}$ & $4.05^{\mathrm{cd}}$ & $5.53^{\mathrm{a}}$ \\
\hline \multirow{7}{*}{$\begin{array}{l}\text { Minimum * } \\
\left(D_{0}\right)\end{array}$} & C & $16.27^{\mathrm{a}}$ & $31.54^{\mathrm{f}}$ & $13.92^{\mathrm{a}}$ & $3.76^{\mathrm{a}}$ & $6.66^{\mathrm{a}}$ & $3.40^{\mathrm{d}}$ & $33.53^{\mathrm{c}}$ & $7.19^{\mathrm{a}}$ & $2.47^{\mathrm{de}}$ & $2.51^{\mathrm{a}}$ \\
\hline & $\mathrm{F}$ & $22.11^{\mathrm{a}}$ & $80.97^{b}$ & $47.66^{a}$ & $4.65^{\mathrm{a}}$ & $11.13^{\mathrm{a}}$ & $11.26^{\mathrm{bc}}$ & $35.29 \mathrm{bc}$ & $9.73^{\mathrm{a}}$ & $5.73^{\mathrm{bc}}$ & $11.13^{\mathrm{a}}$ \\
\hline & $\mathrm{RF}$ & $20.27^{a}$ & $52.17^{d}$ & $36.85^{\mathrm{a}}$ & $9.99^{\mathrm{a}}$ & $9.58^{\mathrm{a}}$ & $2.87^{\mathrm{d}}$ & $30.20^{c}$ & $9.56^{\mathrm{a}}$ & $5.72^{\mathrm{bc}}$ & $4.91^{\mathrm{a}}$ \\
\hline & RFM & $16.86^{\mathrm{a}}$ & $60.41^{\mathrm{cd}}$ & $68.09^{\mathrm{a}}$ & $2.77^{\mathrm{a}}$ & $34.58^{\mathrm{a}}$ & $14.09^{b}$ & $48.39^{\mathrm{a}}$ & $6.09^{\mathrm{a}}$ & $2.92^{\mathrm{de}}$ & $12.33^{\mathrm{a}}$ \\
\hline & RML & $11.53^{\mathrm{a}}$ & $58.73^{\mathrm{cd}}$ & $11.06^{a}$ & $4.65^{\mathrm{a}}$ & $13.31^{\mathrm{a}}$ & $2.58^{\mathrm{d}}$ & $20.33^{\mathrm{d}}$ & $20.59^{\mathrm{a}}$ & $2.59^{\mathrm{de}}$ & $3.89^{\mathrm{a}}$ \\
\hline & RTiM & $13.84^{\mathrm{a}}$ & $27.66^{\mathrm{f}}$ & $34.51^{\mathrm{a}}$ & $7.53^{\mathrm{a}}$ & $8.23^{\mathrm{a}}$ & $9.48^{c}$ & $39.19^{b}$ & $5.49^{\mathrm{a}}$ & $6.48^{\mathrm{b}}$ & $3.38^{\mathrm{a}}$ \\
\hline & RTiP & $17.14^{\mathrm{a}}$ & $32.99^{f}$ & $10.78^{\mathrm{aa}}$ & $2.56^{\mathrm{a}}$ & $7.76^{\mathrm{a}}$ & $3.55^{\mathrm{d}}$ & $5.94^{\mathrm{g}}$ & $22.49^{\mathrm{a}}$ & $1.80^{\mathrm{e}}$ & $6.41^{\mathrm{a}}$ \\
\hline \multicolumn{2}{|l|}{$\underline{P}$} & ns & 0.006 & ns & ns & ns & 0.04 & 0.001 & $\mathrm{~ns}$ & 0.02 & ns \\
\hline
\end{tabular}

SFR, soil fertility resources; F, mineral fertiliser; RF, crop residue + mineral fertiliser; RFM, crop residue + mineral fertiliser + animal manure; RML, crop residue + animal manure + legume intercrop; RTiM, crop

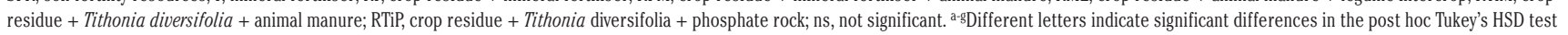
performed in case effects of the model was significant $(\mathrm{P} \leq 0.05)$. 
soil (Nautiyal et al., 2010).

Minimum tillage showed a trend of increased SOC in all the sampled depths at the end of the study and significantly increased SOC content in the 0-5 cm depth in Kandara compared with conventional tillage (Table 6). This could be attributed to the higher physical protection of soil organic matter due to minimized soil disturbance under $\mathrm{D}_{0}$. Increases in $\mathrm{SOC}$ are usually limited to the topmost soil layer of 0-5 cm (Poeplau and Don, 2013; Flávia et al., 2015). In a study conducted in China, on Cambisols, Lou et al. (2012) found that SOC significantly increased under conservation tillage compared to the traditional tillage system under $0-5 \mathrm{~cm}$ depth. Increase in SOC under conservation tillage practices has also been reported by several authors (Dalal et al., 2011; Powlson et al., 2012; Awale et al., 2013). Lack of significant differences in SOC concentrations in response to tillage in deeper depths might be due to the short duration the study was conducted (Geisseler and Horwath, 2009). Application of SFRs' led to positive changes in soil organic carbon.

Generally, use of SFRs with sole organic resources or in combination with mineral fertilizers led to an increment of SOC. Organic resources have a significant impact on increasing soil carbon directly (Mucheru-Muna et al., 2007). Soil fertility resources with animal manure led to increased SOC in our study. Manure application supplies different organic carbon compounds from organic residues to humus which includes the composition of all C fractions resulting in significantly increased root biomass that could return more $\mathrm{C}$ to the soil (Tong et al., 2014). Increase in SOC due to manure application has been reported (Mucheru-Muna et al., 2007). Soil organic carbon increased under RML compared with the control in both sites. The inclusion of legumes increases SOC active pools (Romanyà et al., 2012). Lablab has an extensive root system that aids in improving soil organic carbon (Sheahan, 2012.). Soils under organic management are widely reported to increase and maintain SOC (Chivenge et al., 2011b; Powlson et al., 2012; Lorenz and Lal, 2016). Increased SOC under inorganic fertilizer in Meru South could be due to higher root biomass accumulated over the cropping seasons than in the control plots (Rasool et al., 2008). Mineral fertilizers increase both crop yield and the return of plant residues to the soil and thus can also increase organic matter retention (Romanyà et al., 2012). Other studies have reported that addition of inorganic fertilizers significantly increases SOC stocks (Diekow et al., 2005; Zanatta et al., 2007). However, in the long-term use of mineral fertilizers alone has been shown not capable of increasing SOC compared to organic fertilizers (Triberti et al., 2008; Hai et al., 2010). Crop residue retention is known to enhance SOC, yet, in Kandara use of RF and RFM had no significant difference with the control. This would be attributed to the slow decomposition of maize stover residue and short-term period we conducted the study. In a meta-analysis by Chivenge et al. (2011a) insignificant SOC response under residue retention in clayey soils was also reported.

The bulk of mineral $\mathrm{N}$ found in the soil in all treatments during the two cropping season on all the sampling days was in the form of nitrate-N compared with ammonium-N at both sites. This was as a result of the fast conversion of ammonia to nitrate following mineralization of inputs in the soil as also found by (Shisanya et al., 2009). Mineral-N tended to be high under minimum tillage only at planting, then decreased but increased under conventional tillage as the season progressed. The decrease under minimum tillage could be attributed to reduced soil inversion while the increase under conventional tillage was due to regular soil disturbance that breaks down SOM thus inducing mineralization. Reduced soil disturbance under minimum tillage enhances the for- mation of stable aggregates that physically protect SOM hence reducing mineralization rates (Lichter et al., 2008). We also observed increased soil organic carbon under minimum tillage (Table 6). Continued lack of soil loosening during cropping season slows $\mathrm{N}$ mineralization in minimally tilled soils and promotes denitrification. Conventional tillage induces rapid mineralization of soil nutrients homogenizing distribution of nutrients to the depth of tillage (Johansen et al., 2012) and leading to potential loss of $\mathrm{N}$ from the soil (Abolanle et al., 2015).

The general pattern observed for soil mineral $\mathrm{N}$ content was that greater $\mathrm{N}$ release occurred on the $30^{\text {th }}$ or $45^{\text {th }}$ day after planting and declined on the $60^{\text {th }}$ and $90^{\text {th }}$ at both sites. This could be ascribed to the more rainfall events experienced (Figure 1) around the sampling days leading to increased soil moisture that favors microbial activities. Kaupa and Rao (2014) found that mineralization rates were significantly faster in the first 30 days; later, the rate of release was comparably slower. Soil moisture plays an important role in N mineralization (Qiu-hui et al., 2012). According to Dou et al. (1996), N mineralization shows a two-phase pattern, i.e., the rapid phase and the slow to steady phase. Soil microbes utilize easily decomposable organic $\mathrm{N}$ sources in short periods, leaving more recalcitrant organic matter progressively to be mineralized (Khalil et al., 2005) hence gradually slower rates of mineralization in the later phase. Reduced mineral- $\mathrm{N}$ on the last sampling dates $\left(60^{\text {th }}\right.$ and $\left.90^{\text {th }}\right)$ was probably due to a reduction in microbial populations (Butterly et al., 2009) and a limitation of the solute diffusivity under limited soil moisture conditions (Manzoni et al., 2012). Generally, mineral N was higher during LR17 season compared with the SR16 season in both sites. This was attributed to better rainfall distribution during LR17 season than the SR16 season (Figure 1). Soil mineral $\mathrm{N}$ under the soil fertility resources varied and consequently did not show clear trends which could be attributed to uniform application of crop residues. Mineral $\mathrm{N}$ is readily available from inorganic fertilizers, hence higher mineral $\mathrm{N}$ recorded on first sampling days. Application of mineral $\mathrm{N}$ fertilizer leads to greater mineralization of soil $\mathrm{N}$ from SOM (Kaupa and Rao, 2014). Organic soil fertility resources with high N contents and low C:N ratios mineralize sufficient $\mathrm{N}$ to satisfy plant growth while those with lower $\mathrm{N}$ contents and higher $\mathrm{C}$ : $\mathrm{N}$ ratios can immobilize N (Masunga et al., 2016). Application of crop residues with a high C: $\mathrm{N}$ ratio (Palm et al., 2001) like maize crop residues, may counterbalance the effects of mineralization (Fan et al., 2014). Li et al. (2013) found that soils amended with residues had a lower cumulative $\mathrm{N}$ mineralization than the un-amended soils. Mineralization of $\mathrm{N}$ from crop residues on or near the surface of conservation tillage soils is slower, and $\mathrm{N}$ immobilization is higher than when the residues are incorporated by plowing (Van Den Bossche et al., 2009). Immobilization is also observed in soils with higher clay content (Sakala et al., 2000). Use of RML was not highly significant in mineral-N as expected. Murty et al. (2002) also found that inclusion of leguminous species in the organic system was not effective in adjusting the $\mathrm{C} / \mathrm{N}$ ratio to the lower value for arable soil.

\section{Conclusions}

We evaluated the effect of tillage practices and soil fertility resources on selected soil physical and chemical properties, SOC and mineral $\mathrm{N}$ dynamics under tropical sub-humid agro-ecological conditions. The results highlighted that soil properties are affected by tillage and soil fertility resources. Unlike chemical properties, 
the physical properties were not prominently influenced by the treatments, probably due to the short period the study was conducted. Application of sole organic inputs or in combination with mineral fertilizer showed positive effects on chemical properties. Implementation of minimum tillage, as well as the application of organic soil inputs, showed significant positive effects on soil organic carbon and mineral nitrogen. During the study period, mineral nitrogen was significantly affected by the interactions. Thus our study highlighted that tillage, soil fertility resources application and their combination has effects on soil properties in clayey soils of high agricultural potential areas such as Central Highlands of Kenya. Therefore, we conclude that conservation agriculture practices can offer an opportunity for enhancing and maintaining soil fertility of smallholder agro-ecosystems of sub-Saharan Africa as soil conditions are improved and thus increase crop yields. However, longer-term experimentation would be required to determine the influence of tillage and soil fertility resources on soil physical properties.

\section{References}

Abolanle M, Singh S, Kaur A, Bhatt R, Ally A, 2015. Conservation tillage impacts on soil, crop and the environment. Int. Soil Water Conserv. Res. 3:119-29.

Abraham J, 2013. Organic carbon estimations in soils: Analytical protocols and their implications. Rubber Chem. Technol. 26:45-54.

Agbede TM, 2010. Tillage and fertilizer effects on some soil properties, leaf nutrient concentrations, growth and sweet potato yield on an Alfisol in southwestern Nigeria. Soil Tillage Res.110:25-32.

Antichi D, Risaliti R, Mazzoncini M, Bahadur T, Ba P, 2011. Longterm effect of tillage, nitrogen fertilization and cover crops on soil organic carbon and total nitrogen content. Soil Tillage Res. 114:165-74.

Askari MS, Holden NM, 2015. Quantitative soil quality indexing of temperate arable management systems. Soil Tillage Res. 150:57-67.

Awale R, Chatterjee A, Franzen D, 2013. Tillage and N-fertilizer influences on selected organic carbon fractions in a North Dakota silty clay soil. Soil Tillage Res. 134:213-22.

Baker JM, Ochsner TE, Venterea RT, Griffis TJ, 2007. Tillage and soil carbon sequestration-What do we really know? Agric. Ecosyst. Environ. 118:1-5.

Balkcom KS, Blackmer M, Hansen DJ, 2009. Measuring Soil Nitrogen Mineralization under Field Conditions. Commun. Soil Sci. Plan. 40:1073-86.

Baumhardt RL, Jones OR, 2002. Residue management and paratillage effects on some soil properties and rain infiltration. Soil Tillage Res. 65:19-27.

Bechtold JS, Naiman RJ, 2006. Soil texture and nitrogen mineralization potential across a riparian toposequence in a semiarid savanna. Soil Biol. Biochem. 38:1325-33.

Brady NC, 1990. The Nature and Properties of Soils, 3rd edn. Macmillan, London, UK.

Bronick CJ, Lal R. 2005. Soil structure and management: a review. Geoderma 124:3-22.

Busari MA, Kukal SS, Kaur A, Bhatt R, Dulazi AA, 2015. Conservation tillage impacts on soil, crop and the environment. Int. Soil Water Conserv. Res. 3:119-29.

Butterly CR, Buenemann EK, McNeill AM, Baldock JA,
Marschner P, 2009. Carbon pulses but not phosphorus pulses are related to decreases in microbial biomass during repeated drying and rewetting of soils. Soil Biol. Biochem. 41:1406-16.

Caia A, Xua M, Wanga B, Zhanga W, Liang G, Hou E, Luo Y, 2019. Manure acts as a better fertilizer for increasing crop yields than synthetic fertilizer does by improving soil fertility. Soil Tillage Res. 189:168-75.

Chivenge P, Vanlauwe B, Six J, 2011a. Does the combined application of organic and mineral nutrient sources influence maize productivity? A meta-analysis. Plant Soil 342:1-30.

Chivenge P, Vanlauwe B, Gentile R, Six J, 2011b. Organic resource quality influences short-term aggregate dynamics and soil organic carbon and nitrogen accumulation. Soil Biol Biochem. 43:657-66.

Dalal RC, Allen DE, Wang WJ, Reeves S, Gibson I, 2011. Organic carbon and total nitrogen stocks in a Vertisol following 40 years of no-tillage, crop residue retention and nitrogen fertilization. Soil Tillage Res. 112:133-9.

Diekow J, Mielniczuk J, Knicker H, Bayer C, Dick DP, KogelKnabner I, 2005. Soil C and N stocks as affected by cropping systems and nitrogen fertilization in Southern Brazil Acrisol managed under no-tillage for 17 years. Soil Tillage Res. 81:87-95.

Divito GA, 2012. Fertilization and tillage effects on soil properties and maize yield in a Southern Pampas Argiudoll. Soil Tillage Res. 119: 22-30.

Dou Z, Toth JD, Jabro JD, Fox RH, Fritton DD, 1996. Soil nitrogen mineralization during laboratory incubation: dynamics and model fitting. Soil Biol. Biochem. 28:625-32.

Drinkwater LE, 2004. Improving nitrogen fertilizer use efficiency through an ecosystem-based approach. In: Mosier, A.R., Syers, J.K., Freney, J.R. (Eds.), Agriculture and the Nitrogen Cycle: Assessing the Impacts of Fertilizer Use on Food Production and the Environment. SCOPE Nitrogen Fertilizer RAP, vol. 65. Island Press, Washington, DC, pp. 93-102.

Estavillo JM, Merino P, Pinto M, Yamulki S, Gebauer G, Sapek A, Corre W, 2002. Short term effect of ploughing a permanent pasture on $\mathrm{N} 2 \mathrm{O}$ production from nitrification and denitrification. Plant Soil 239:253-65.

Fan Z, Lin S, Zhang X, Jiang Z, Yang K, Jian D, Chen Y, Li J, Chena Q, Wang J, 2014. Conventional flooding irrigation causes an overuse of nitrogen fertilizer and low nitrogen use efficiency in intensively used solar greenhouse vegetable production. Agric. Water Manag. 144:11-9.

Ferreras LA, Costa JL, Garcia FO, Pecorari C, 2000. Effect of notillage on some soil physical properties of a structural degraded Petrocalcic Paleudoll of the southern "Pampa" of Argentina. Soil Tillage Res. 54:31-9.

Fertilizer Use Recommendation Project (FURP), 1987. Description of first priority trial site in the various Districts. Fertilizer Use Recommendation Project (FURP), vol. 24 National Agricultural Research Laboratories, Embu District, Nairobi, Kenya.

Flávia É, Pinheiro M, Vilas D, Campos BD, 2015. Tillage systems effects on soil carbon stock and physical fractions of soil organic matter. Agric. Syst. 132:35-9.

Garcia-franco N, Albaladejo J, Almagro M, Martínez-mena M, 2015. Beneficial effects of reduced tillage and green manure on soil aggregation and stabilization of organic carbon in a Mediterranean agroecosystem. Soil Tillage Res. 153:66-75.

Geisseler D, Horwath WR, 2009. Short-term dynamics of soil carbon, microbial biomass, and soil enzyme activities as compared to longer-term effects of tillage in irrigated row crops. Biol. Fertil. Soils 46:65-72. 
Ghosh S, Wilson B, Ghoshal S, Senapati N, Mandal B, 2012. Organic amendments influence soil quality and carbon sequestration in the Indo-Gangetic plains of India. Agric. Ecosyst. Environ.156:134-41.

Ghuman BS, Sur HS, 2001. Tillage and residue management effects on soil properties and yields of rainfed maize and wheat in a subhumid subtropical climate. Soil Tillage Res. 58:1-10.

Gicheru P, Gachene C, Mbuvi J, Mare E, 2004. Effects of soil management practices and tillage systems on surface soil water conservation and crust formation on a sandy loam in semi-arid Kenya. Soil Tillage Res. 75:173-84.

Gomez E, Ferreras L, Toresani S, Ausilio A, Bisaro V, 2001. Changes in some soil properties in a Vertic Argiudoll under short-term conservation tillage. Soil Tillage Res. 61:179-86.

Hai L, Gang X, Min F, Rang D, Guggenberger G, 2010. Long-term fertilization and manuring effects on physically-separated soil organic matter pools under a wheat-wheat-maize cropping system in an arid region of China. Soil Biol. Biochem. 42:253-9.

Hue NV, 1992. Correcting soil acidity of a highly weathered ultisol with chicken manure and sewage sludge. Commun. Soil Sci. Plan. 23:241-64.

Ismail L, Blevins RL, Frye WW, 1994. Long-term no-tillage effects on soil properties and continuous corn yields. Soil Sci. Soc. Am. J. 58:193-8.

Jaetzold R, Schmidt H, Hornet ZB, Shisanya CA, 2007. Farm Management Handbook of Kenya. Natural Conditions and Farm Information. 2nd Edition. Vol.11/ C. Eastern Province. Ministry of Agriculture/GTZ, Nairobi, Kenya.

Jagadamma S, Lal R, Hoeft RG, Nafziger ED, Adee EA, 2007. Nitrogen fertilization and cropping systems effects on soil organic carbon and total nitrogen pools under chisel-plow tillage in Illinois. Soil Tillage Res. 95:348-56.

Jama B, Palm CA, Buresh R.J, Niang A, Gachengo C, Nziguheba G, Amadalo B, 2000. Tithonia diversifolia as a green manure for soil fertility improvement in western Kenya: a review. Agrofor. Syst. 49:201-21.

Johansen C, Haque ME, Bell RW, Thierfelder C, Esdaile RJ, 2012. Conservation agriculture for smallholder rainfed farming: Opportunities and constraints of new mechanized seeding systems. F. Crop. Res. 132:18-32.

Kaupa P, Rao BKR, 2014. Nitrogen mineralization and efficiency from co-applied animal manures and mineral fertilizer in sweet potato under humid tropical conditions. F. Crop. Res. 168:48-56.

Kemper WD, Rosenau RC, 1986. Aggregate stability and size distribution. In: Klute, A. (Ed.), Methods of Soil Analysis. Part 1. Physical and mineralogical methods. SSSA,

Khalil ML, Hossain MB, Schmidhalter U, 2005. Carbon and nitrogen mineralization in different upland soils of the subtropics treated with organic materials. Soil Biol. Biochem. 37:1507-18.

Kiboi MN, Ngetich KF, Diels J, Mucheru-Muna M, Mugwe J, Mugendi DN, 2017. Minimum tillage, tied ridging and mulching for better maize yield and yield stability in the Central Highlands of Kenya. Soil Tillage Res. 170:157-66.

Kiboi MN, Ngetich KF, Mugendi DN, Muriuki A, Adamtey N, Fliessbach A, 2018. Microbial biomass and acid phosphomonoesterase activity in soils of the Central Highlands of Kenya. Geoderma Reg. e00193.

Klute A, Dirksen C, 1986. Hydraulic conductivity and diffusivity: Laboratory methods. In: A. Klute (Editor), Methods of Soil Analysis, Part 1, 2nd ed. Agronomy Monograph 9, ASA, Madison, WI, pp. 687-732.

Korodjouma O, Badiori O, Ayemou A, 2006. Long-term effect of ploughing, and organic matter input on soil moisture character- istics of a Ferric Lixisol in Burkina Faso. Soil Tillage Res. 88: 217-24.

Leite LFC, Oliveira FC, Araújo ASF, Galvão SRS, Lemos JO, Silva EFL, 2010. Soil organic carbon and biological indicators in an Acrisol under tillage systems and organic management in north-eastern Brazil. Aust. J. Soil Res. 48:258-65.

Li L, Han X, You M, Yuan Y, Ding X, Qiao Y, 2013. Carbon and nitrogen mineralization patterns of two contrasting crop residues in a Mollisol: Effects of residue type and placement in soils. Eur. J. Soil Biol. 54:1-6.

Lichter K, Govaerts B, Six J, Sayre KD, Deckers J, Dendooven L, 2008. Aggregation and $\mathrm{C}$ and $\mathrm{N}$ contents of soil organic matter fractions in the permanent raised-bed planting system in the Highlands of Central Mexico. Plant Soil. 305:237-52.

Lobell DB, 2007. The cost of uncertainty for nitrogen fertilizer management: A sensitivity analysis. F. Crop. Res. 100: 210-7.

Logsdon SD, Karlen DL, 2004. Bulk density as a soil quality indicator during conversion to no-tillage. Soil Tillage Res. 78:143-9.

Lorenz K, Lal R, 2016. Environmental Impact of Organic Agriculture. Adv. Agron. 139: 99-152.

Lou Y, Xu M, Chen X, He X, Zhao K, 2012. Strati fi cation of soil organic $\mathrm{C}, \mathrm{N}$ and $\mathrm{C}: \mathrm{N}$ ratio as affected by conservation tillage in two maize fields of China. Catena 95:124-30.

Lyles L, Dickerson JD, Disrud LA, 1970. Modified rotary sieve for improved accuracy. Soil Sci. 109:207-10.

Macci C, Doni S, Peruzzi E, Masciandaro G, Mennone C, Ceccanti B, 2012. Almond tree and organic fertilization for soil quality improvement in southern Italy. J. Environ. Manage. 95:S215-22.

Mäder P, Fliessbach A, Dubois D, Gunst L, Fried P, Niggli U, 2002. Soil fertility and biodiversity in organic farming. Science 296:1694-7.

Mandal UK, Singh G, Victor US, Sharma KL, 2003. Green manuring: its effect on soil properties and crop growth under ricewheat cropping system. Eur. J. Agron. 19:225-37.

Mangalassery S, Mooney SJ, Sparkes DL, Fraser WT, Sjogersten S, 2015. Impacts of zero tillage on soil enzyme activities, microbial characteristics and organic matter functional chemistry in temperate soils. Eur. J. Soil Biol. 68:9-17.

Manzoni S, Schimel JP, Porporato A, 2012. Responses of soil microbial communities to water stress: results from a metaanalysis. Ecology 93:930-8.

Mariangela D, Francesco M, 2010. Long-term effects of organic amendments on soil fertility. A review. Agron. Sustain. Dev. 30:401-22.

Masunga RH, Uzokwe VN, Mlay PD, Odeh I, Singh A, Buchan D, Neve SD, 2016. Nitrogen mineralization dynamics of different valuable organic amendments community used in agriculture. Appl. Soil Ecol. 101:185-93.

Meena JR, Behera UK, Chakraborty D, Sharma AR, 2015. Tillage and residue management effect on soil properties, crop performance and energy relations in greengram (Vigna radiata L.) under maize-based cropping systems. Int. Soil Water Conserv. Res. 3:261-72.

Mehlich A, 1984. Mehlich 3 soil test extractant: a modification of Mehlich 2 extractant. Commun. Soil Sci. Plan. 15:1409-16.

Melero S, Madej E, Carlos J, Francisco J, 2007. Chemical and biochemical properties of a clay soil under dryland agriculture system as affected by organic fertilization. Eur. J. Agron. 26:327-34.

Mellek E, Dieckow J, Lopes V, Favaretto N, Pauletti V, Vezzani FM, Luiz J, Souza MD, 2010. Dairy liquid manure and notillage: Physical and hydraulic properties and carbon stocks in a Cambisol of Southern Brazil. Soil Tillage Res. 110:69-76. 
Mijangos I, Garbisu C, 2010. Consequences of soil sampling depth during the assessment of the effects of tillage and fertilization on soil quality: a common oversight. Soil Tillage Res. 109:169-73.

Mosaddeghi MA, Hajabbasi MA, Hemmat A, Afyuni M, 2000. Soil compactibility as affected by soil moisture content and farmyard manure in central Iran. Soil Tillage Res. 55:87-97.

Motavalli PP, Anderson SH, Pengthamkeerati P, 2003. Surface compaction and poultry litter effects on corn growth, nitrogen availability, and physical properties of a clay pan soil. F. Crop. Res. 84:303-18.

Mucheru-Muna M, Mugendi D, Kung'u J, Mugwe J, Bationo A, 2007. Effects of organic and mineral fertilizer inputs on maize yield and soil chemical properties in a maize cropping system in Meru South District, Kenya. Agrofor. Syst. 69:189-97.

Mucheru-Muna M, Mugendi D, Pypers P, Mugwe J, Kung'u J, Vanlauwe B, Merckx R, 2014. Enhancing maize productivity and profitability using organic inputs and mineral fertilizer in central Kenya small-hold farms. Exp. Agric. 50:250-69.

Mulumba LN, Lal R, 2008. Mulching effects on selected soil physical properties. Soil Tillage Res. 98:106-111.

Murty D, Kirschbaum MUF, Mcmurtrie RE, 2002. Does conversion of forest to agricultural land change soil carbon and nitrogen? A review of the literature. Global Change Biol. 8:105-23.

Nautiyal CS, Chauhan PS, Bhatia CR, 2010. Changes in soil physico-chemical properties and microbial functional diversity due to 14 years of conversion of grassland to organic agriculture in semi-arid agroecosystem. Soil Tillage Res. 109:55-60.

Nivelle E, Verzeaux J, Habbib H, Kuzyakov Y, Decocq G, Roger D, Lacouxa J, Duclercqa J, Spichera F, Nava-Saucedoa J, Catteroua M, Duboisa F, Tetu T, 2016. Functional response of soil microbial communities to tillage, cover crops and nitrogen fertilization. Appl. Soil Ecol. 108:147-55.

Okeyo IA, Mucheru-Muna M, Mugwe J, Ngetich KF, Mugendi DN, Diels J, Shisanya CA, 2014. Effects of selected soil and water conservation technologies on nutrient losses and maize yields in the central highlands of Kenya. Agric. Water Manag. 137:52-8.

Onwonga RN, Namoi NL, Lelei JJ, 2015. Influence of organic based technologies on soil nutrient status in semi-arid Yatta sub-County, Kenya. J. Agric. Sci. 7:56-80.

Palm CA, Gachengo CN, Delve RJ, Cadisch G, Giller KE, 2001. Organic inputs for soil fertility management in tropical agroecosystems: application of an organic resource database. Agric. Ecosyst. Environ. 83:27-42.

Paul BK, Vanlauwe B, Ayuke F, Gassner A, Hoogmoed M, Hurisso TT, Koala S, Lelei D, Ndabamenye T, Six J, Pulleman MM, 2013. Medium-term impact of tillage and residue management on soil aggregate stability, soil carbon and crop productivity. Agric. Ecosyst. Environ. 164:14-22.

Peck GM, Merwin IA, Thies JE, Schindelbeck RR, Brown MG, 2011. Soil properties change during the transition to integrated and organic apple production in a New York orchard. Appl. Soil Ecol. 48:18-30.

Peichl M, Leava NA, 2012. Above- and below ground ecosystem biomass, carbon and nitrogen allocation in recently afforested grassland and adjacent intensively managed grassland. Plant Soil 350:281-96.

Poeplau C, Don A, 2013. Sensitivity of soil organic carbon stocks and fractions to different land-use changes across Europe. Geoderma 192:189-201.

Powlson DS, Bhogal A, Chambers BJ, Coleman K, Macdonald AJ, Goulding KWT, Whitmore, AP, 2012. The potential to increase soil carbon stocks through reduced tillage or organic material additions in England and Wales: A case study. Agric. Ecosyst. Environ. 146:23-33.

Powlson DS, Gregory PJ, Whalley WR, Quinton JN, Hopkins DW, Whitmore AP, Hirsch PR, 2011. Soil management in relation to sustainable agriculture and ecosystem services. Food Policy 36:572-87.

Qiu-hui C, Ying F, Yan-ping Z, Qi-chun Z, Shamsi IH, Yong-song Z, 2012. Short-Term Responses of Nitrogen Mineralization and Microbial Community to Moisture Regimes in Greenhouse Vegetable Soils. Pedosph. An Int. J. 22:263-72.

Rasool R, Kukal SS, Hira GS, 2008. Soil organic carbon and physical properties as affected by long-term application of FYM and inorganic fertilizers in maize-wheat system. Soil Tillage Res. 101:31-6.

Romanyà J, Arco N, Solà-Morales I, Armengot L, Sans FX, 2012. Carbon and Nitrogen Stocks and Nitrogen Mineralization in Organically Managed Soils Amended with Composted Manures. .J. Environ. Qual. 41:1337.

Rufino MC, Rowe EC, Delve RJ, Giller KE, 2006. Nitrogen cycling efficiencies through resource-poor African crop livestock systems. Agric. Ecosyst. Environ. 112:261-82.

Ryan J, George E, Rashid A, 2001. Soil and plant analysis laboratory manual. Jointly Published by International Center for Agricultural Research in the Dry Areas (ICARDA) and the National Agricultural Research Centre (NARC), second edition. pp. 46-48.

Sakala WD, Cadisch G, Giller KE, 2000. Interactions between residues of maize and pigeonpea and mineral $\mathrm{N}$ fertilizers during decomposition and $\mathrm{N}$ mineralization. Soil Biol. Biochem. 32:679-88.

SAS Institute, 2011. SAS/STAT 9.3 User's Guide. SAS Institute Inc., Cary, NC, USA.

Saygin SD, Erpul G, Basaran M, 2015. Comparison of aggregate stability measurement methods for clay-rich soils in asartepe catchment of Turkey. Land Degrade. Develop. 28:199-206.

Scotti R, Conte P, Berns AE, Alonzo G, Rao MA, 2013. Effect of organic amendments on the evolution of soil organic matter in soils stressed by intensive agricultural practices. Curr. Org. Chem. 17: 2998-3005.

Sheahan CM, 2012. Plant guide for lablab (Lablab purpureus). USDA-Natural resources Conservation Service, Cape May Plant Materials Center. Cape May, NJ. 08210.

Shisanya CA, Mucheru MW, Mugendi DN, Kungu JB, 2009. Effect of organic and inorganic nutrient sources on soil mineral nitrogen and maize yields in central highlands of Kenya. Soil Tillage Res. 103:239-46.

Sun B, Hallett PD, Caul S, Daniell TJ, Hopkins DW, 2011. Distribution of soil carbon and microbial biomass in arable soils under different tillage regimes. Plant Soil 338:17-25.

Tiritan CS, Büll LT, Crusciol CAC, Carmeis Filho ACA, Fernandes DM, Nascente AS, 2016. Tillage system and lime application in a tropical region: Soil chemical fertility and corn yield in succession to degraded pastures. Soil Tillage Res. 155:437-47.

Tong X, Xu M, Wang X, Bhattacharyya R, Zhang W, Cong R, 2014. Long-term fertilization effects on organic carbon fractions in a red soil of China. Catena 113:251-9.

Triberti L, Nastri A, Giordani G, Comellini F, Baldoni G, Toderi G, 2008. Can mineral and organic fertilization help sequestrate carbon dioxide in cropland? Eur. J. Agron. 29:13-20.

Van Den Bossche A, De Bolle S, De Neve S, Hofman G, 2009. Effect of tillage intensity on $\mathrm{N}$ mineralization of different crop 
residues in a temperate climate. Soil Tillage Res. 103:316-24.

Vanlauwe B, Kihara J, Chivenge P, Pypers P, Coe R, Six J, 2011. Agronomic use efficiency of $\mathrm{N}$ fertilizer in maize-based systems in Sub-Saharan Africa within the context of integrated soil fertility management. Plant Soil 339:35-50.

Vieira RF, Silva CMMS, Silveira APD, 2007. Soil microbial biomass $\mathrm{C}$ and symbiotic processes associated with soybean after sulfentrazone herbicide application. Plant Soil 300:95-103.

Wang XB, Cai DX, Perdok UD, Hoogmoed WB, Oenema O, 2007. Development in conservation tillage in rainfed regions of North China. Soil Tillage Res. 93:239-50.

Willekens K, Vandecasteele B, Buchan D, Neve SDe, 2014. Soil quality is positively affected by reduced tillage and compost in an intensive vegetable cropping system. Appl. Soil Ecol. 82:61-71.

Wood SA, Bradford MA, Gilbert JA, McGuire KL, Palm CA,
Tully K, Zhou J, Naeem S, 2015. Efforts to increase crop yield among smallholder farmers in western Kenya are synergistic with greater functional capacity of soil microbial communities. J. Appl. Ecol. 52:744-52.

Wyngaard N, Echeverría HE, Rozas HRS, Divito GA, 2012. Fertilization and tillage effects on soil properties and maize yield in a Southern Pampas Argiudoll. Soil Tillage Res. 119:22-30.

Yang X, Ren W., Sun B, Zhang S, 2012. Effects of contrasting soil management regimes on total and labile soil organic carbon fractions in a loess soil in China. Geoderma 177-178:49-56.

Zanatta JA, Bayer C, Dieckow J, Vieira FCB, Mielniczuk J, 2007. Soil organic carbon accumulation and carbon costs related to tillage, cropping systems and nitrogen fertilization in a subtropical Acrisol. Soil Tillage Res. 94:510-9. 